\title{
Increased temperature-related adeno-associated virus vectors transduction of ovarian cancer cells - essential signatures of AAV receptor and heat shock proteins
}

\author{
ALICJA BIEŃKOWSKA ${ }^{1}$, MAGDALENA DUCHER ${ }^{1}$, MAGDALENA ORZECHOWSKA ${ }^{1}$, \\ ŻANETA SŁYK ${ }^{1}$, OLGA CIEPIELA ${ }^{2}$, JANUSZ JAWOROWSKI ${ }^{3}$ and MACIEJ MAŁECKI ${ }^{1}$
}

\author{
${ }^{1}$ Department of Applied Pharmacy, Faculty of Pharmacy with Laboratory Medicine, Medical University of Warsaw, \\ Warsaw 02-097; ${ }^{2}$ Department of Laboratory Diagnostics, Faculty of Medicine, Medical University of Warsaw, \\ Warsaw 02-091; ${ }^{3}$ Timeless Plastic Surgery Clinic, Warsaw 03-982, Poland
}

Received December 11, 2018; Accepted July 30, 2019

DOI: $10.3892 /$ etm.2019.8112

\begin{abstract}
Recombinant adeno-associated viruses (rAAVs) are becoming more commonly used in clinical trials involving gene therapy. Additionally AAV-based drugs have already been registered. Gene therapy aims to increase transduction efficiency, increase in vivo selectivity and reduce side effects. One approach to achieve this is the use of physical factors, such as temperature or more specifically, hyperthermia, which is already utilized in oncology. The aim of the present study was to investigate the effect of hyperthermic conditions $\left(40^{\circ} \mathrm{C}\right.$ and $\left.43^{\circ} \mathrm{C}\right)$ on the rAAV transduction efficiency of ovarian cancer cells (Caov-3 and NIH:OVCAR-3) and non-cancerous cells (AAV-293). The present study was designed to identify functional associations between the level of gene transfer and the expression of representative genes for rAAV transmission (AAVR (AAV receptor), heparan sulfate proteoglycan (HSPG) 1 and HSPG2) and heat shock proteins (HSPs). The expressions of selected genes were measured via reverse transcription-quantitative PCR and cell adhesion/invasion chamber tests were also performed. The results revealed that ovarian cancer cell lines were more efficiently transduced with rAAV vectors at an elevated temperature. Additionally, the expression patterns of AAVR, HSPG1 and HSPG2 genes were different between the tested lines. The expression of certain receptors in ascites-derived NIH:OVCAR-3 ovarian cancer cells was higher compared with tumor-derived Caov-3 cells at 37,40 and $43^{\circ} \mathrm{C}$, which indicates a higher transduction efficiency in the formerly mentioned cells. Ascites-derived
\end{abstract}

Correspondence to: Miss Alicja Bieńkowska, Department of Applied Pharmacy, Faculty of Pharmacy with Laboratory Medicine, Medical University of Warsaw, 1 Banacha Street, Warsaw 02-097, Poland

E-mail: alicja.bienkowska@wum.edu.pl

Key words: adeno-associated viruses, gene transfer, hyperthermia, ovarian cancer ovarian cancer cells were characterized by high expressions of HSP40, HSP90 and HSP70 families. Lower levels of HSP expression were demonstrated in less-effectively transduced Caov-3 cells. Furthermore, expressions of the examined genes changed with increasing temperature. The results indicated that temperature-dependent transduction is associated with the expression of the rAAV receptor and HSP genes. The results of the current study may aid the design of effective protocols for ovarian cancer gene therapy.

\section{Introduction}

Adeno-associated viruses (AAV) are small (a diameter of approximately $25 \mathrm{~nm}$ ), non-encapsulated, icosahedral viruses. They are classified as members of the Parvoviridae family, the Dependovirus genus. AAV can replicate only in the presence of helper viruses, such as adenovirus, herpes simplex virus and human papilloma virus (1). The contribution of genotoxic factors in the activation of AAV replication is also indicated (2). The AAV genome is single-stranded DNA (approximately $4.7 \mathrm{~kb}$ ) consisting mainly of two reading frames: the rep and cap genes, and ITR flanking sequences. The expression cassette in recombinant vectors, containing the promoter and the transgene, is cloned in place of deleted rep and cap genes, between 145 nucleotides ITR sequences (1). Due to the non-pathogenic nature and occurrence of serotypes with defined organ tropism, recombinant AAV vectors are increasingly used in gene therapy trials (3). There already are registered AAV-based drugs (3). The safety of rAAV vectors as well as their presence in medicine result in a number of studies revealing critical points in the pathway of gene transfer and intracellular events involving $\mathrm{rAAV}(1,4)$. The role of the miRNA signature (5) and the expression of AAV membrane receptors (6-8) in the AAV cellular transmission are in the course of documentation. Discovering cellular mechanisms of rAAV transduction helps to understand the AAV biology and makes it possible to design new vectors-synthetic AAV mosaic serotypes (9), vectors with dsDNA (10), AAV chemoconjugates (11). There is research indicating the possibilities of optimizing the efficiency of rAAV transduction by various 
physicochemical treatments. The increase of rAAV transduction efficiency is observed as a result of hyperthermia (12). Also, the use of proteasome inhibitors and the degradation of proteins associated with endoplasmic reticulum induce the same effect $(13,14)$. The possibility of physicochemical manipulation of transduction efficiency significantly increases the use of bio-safe AAV vectors in gene therapy.

The normal temperature of the human body, around $37^{\circ} \mathrm{C}$, is a condition for maintaining homeostasis and is necessary for the course of physiological processes. Thermoregulation is crucial in the context of maintaining the continuity of human life, and it is based on many well-defined and complex physiological processes controlled by the function of the thermoregulation center, the vasomotor system and the skin. Incorrect temperature fluctuations, which go beyond the range of the menstrual cycle or the aging of the body, cause changes in the functioning of relevant cellular biomolecules, including protein denaturation and irreversible DNA damage. Exceeding the thermoregulatory thresholds results in disturbances in the essential function of cardiovascular, nervous and respiratory systems (15-18). Temperature modulation is also the basis for the development of new biomaterials and therapeutic technologies (19). The synthesis of thermally sensitive hydrogels allows the design of controlled drug release systems in response to an external stimulus, such as temperature (20). Controlled temperature increase is also the basis of oncological hyperthermia (21). Local or whole-body hyperthermia is considered a complementary therapy in oncology, in combination with chemotherapy or radiotherapy $(21,22)$.

Cell profiling in terms of their temperature sensitivity, e.g., by evaluating expression of heat shock proteins (HSP) or transient receptor potential (TRP) channels, is important for the design of new temperature-regulating drugs and medical technologies, also in the field of gene therapy $(23,24)$. The temperature response of cells is closely related to the heat shock protein family gene expression pattern. HSPs are classified based on molecular weight and function (e.g., HSP27, HSP70, HSP90). HSP biosynthesis is precisely regulated by the activity of transcription factors (HSF) that recognize heat shock elements in the promoter regions of genes. HSPs are involved in the folding, maturation, functioning and degradation of many crucial proteins (being chaperones they interact with many proteins). Therefore, they perform regulatory functions in the fundamental biological processes such as proliferation, apoptosis, drug resistance, stress response (25-27). HSP signatures in cells are different, there are significant differences in the constitutive expression of HSP genes in tumor cells, which are associated with the pathomechanisms of cancer development $(28,29)$. In ovarian cancers, the important role of HSP27, HSP70 and HSP90 is stressed (29). It is documented that HSP expression changes under stress conditions, and individual HSPs can be expressed at different levels. The role of HSP90 in AAV transduction to cells is emphasized, underlining functional relationships between FKBP52 and HSP90 (12,27,30). The phosphorylated form of the FKBP52 chaperone protein has been shown to interact with the D-sequence of the ITRs in the AAV genome. It inhibits the synthesis of the second viral DNA strand and thereby leads to inefficient expression of the transgene from the rAAV vector. The heat shock leads to the dephosphorylation of
FKBP52, stabilization of the FKBP52-HSP90 complex, which results in the increase of rAAV transduction efficiency $(12,30)$. It seems that the transduction efficiency of rAAV depends on the cells HSP signatures. The level of selected HSPs in the cells promotes an increase the transduction efficiency with the use of AAV vectors. It is worth considering that the determination of the HSP signature in tumors may be helpful in planning efficient gene therapy trials.

At present, gene therapy of ovarian cancers is based primarily on the use of suppressor gene (e.g., WWOX) strategies, suicide therapy (e.g., HVS-TK), anti-angiogenic strategy (e.g., VEGF) and a strategy directed towards multidrug resistance genes (e.g., MDR1) or based on oncolytic virotherapy (31). Despite progress in the field of ovarian gene therapy, there are too few clinical trials on oncology patients and there is still a lack of efficient and safe gene transfer systems. The aim of this study was to investigate the effect of hyperthermia conditions $\left(40\right.$ and $43^{\circ} \mathrm{C}$ ) on the rAAV transduction efficiency of ovarian cancers with various clinical origins. Moreover, the purpose was to evaluate the expression of representative genes involved in rAAV transmission with special emphasis on heat shock protein genes. Notably, depending on the origin of ovarian cancer cells, the increase of rAAV transduction efficiency at elevated temperature was subsequently the cause of the search for functional linkages between the high sensitivity of ascites-derived ovarian cancer to $\mathrm{AAV}$, and for the expression of representative genes for rAAV transmission and HSP.

\section{Materials and methods}

Cell lines. The ovarian cancer cell lines with a different clinical origin (32,33): Caov-3 (ATCC ${ }^{\circledR}$ HTB-75), NIH:OVCAR-3 (ATCC ${ }^{\circledR}$ HTB-161, American Type Culture Collection) were cultured in the Dulbecco's Modified Eagle Medium (DMEM; Gibco; Thermo Fisher Scientific, Inc.) supplemented with 10\% FBS (Gibco; Thermo Fisher Scientific, Inc.) and RPMI Medium-1640 (Gibco; Thermo Fisher Scientific, Inc.) supplemented with $20 \% \mathrm{FBS}$ and $0.6 \mathrm{mg}$ insulin (Insulin solution from bovine pancreas; Sigma-Aldrich; Merck $\mathrm{KGaA} / 500 \mathrm{ml}$ medium, respectively. Cell line AAV-293 (Agilent Technologies) derived from human embryonic kidney cells was cultured in DMEM supplemented with 10\% FBS. Human fibroblasts CCD-18Co (ATCC ${ }^{\circledR}$ CRL-1459) were cultured in Minimum Essential Media (Gibco; Thermo Fisher Scientific, Inc.) supplemented with $10 \%$ FBS. The media were also supplemented with $1 \%$ Antibiotic-Antimycotic (Gibco; Thermo Fisher Scientific, Inc.), and the cells were maintained at $37^{\circ} \mathrm{C}$ in a humidified $5 \% \mathrm{CO}_{2}$ atmosphere. Mycoplasma test was performed in our laboratory, and its shown no contamination. The analyzed cells were verified in the International Cell Line Authentication Committee and ExPASy Cellosaurus databases $(34,35)$, in order to exclude their contamination with other cell lines or their incorrect identification.

rAAV transduction at hyperthermia conditions. Cells were seeded at the density $1 \times 10^{5}$ for Caov-3, AAV-293 and $1.5 \times 10^{5}$ for NIH:OVCAR-3 per a $6 \mathrm{~cm}$ diameter dish in the appropriate medium and incubated for $24 \mathrm{~h}$ in a normal culture condition. Just before transduction, cell culture media were 
replaced with adequate ones (AAV-293, Caov-3-DMEM; NIH:OVCAR-3-RPMI-1640 with insulin) heated up to 37, 40 or $43^{\circ} \mathrm{C}$ with FBS reduced to $2 \%$. To transduce the ovarian cancer cells, the recombinant AAV vector $\mathrm{rAAV} / \mathrm{DJ}-\mathrm{cmv}$ eGFP (cat. no: 7101; Vector Biolabs) was added to the new, heated media with the multiplicity of infection (MOI) of $4 \times 10^{4}$ genome copies or 0 genome copies (non-transduction control group). The vector $\mathrm{rAAV} / \mathrm{DJ}-\mathrm{cmv}$-GFP expresses eGFP gene under a control of $\mathrm{cmv}$ promoter. To test the promoters' transcriptional activity, AAV-293 cells were transfected with rAAV/DJ-CAG-GFP (cat. no: 7078; Vector Biolabs) at the same conditions and MOI. The vector rAAV/DJ-CAG-GFP expresses eGFP gene under a control of CAG promoter. The cells were incubated for $3 \mathrm{~h}$ in hyperthermia conditions $\left(40\right.$ or $43^{\circ} \mathrm{C}$ ) in a humidified $5 \% \mathrm{CO}_{2}$ atmosphere. Then the cells were moved to $37^{\circ} \mathrm{C}$. After 48 and $96 \mathrm{~h}$ of transduction, the cell culture media were replaced with fresh $2 \%$ FBS media. Finally, the cells were harvested on the 6th day after transduction.

Non-transduction cells were examined to test HSP (Caov-3 and NIH:OVCAR-3) and AAV receptor (CCD-18Co, AAV-293, Caov-3 and NIH:OVCAR-3) expression. They were harvested after $24 \mathrm{~h}$ from exposure to hyperthermia conditions.

Transduction efficiency measurement. The Countess II FL Automated Cell Counter (Invitrogen; Thermo Fisher Scientific, Inc.) with EVOS Light Cube-GFP (470/22 nm Excitation; 510/42 nm Emission) was used to determine the percentages of Green Florescent Protein-positive (GFP+) cells. The images of GFP-expressing cells were obtained using an inverted fluorescence microscope (Olympus IX53; Olympus) with the $\mathrm{pE}-300^{\text {white }}$ (CoolLED) illumination system. Pictures of non-transduced (in BF) and transduced (in FITC) cells were taken at X10 magnification. All measurements were performed on the 6th day after transduction, before the cells harvesting for DNA isolation to analyze the transduction efficiency by qPCR.

Quantitative (q)PCR for AAV genome copy number determination. Total DNA was isolated using the High Pure Viral Nucleic Acid kit (Roche Life Science) from AAV-293, Caov- 3 and NIH:OVCAR-3 cell lines. The amount of DNA was quantified by $260 / 280 / 230 \mathrm{~nm}$ absorbance measurements using spectrophotometer Quawell Q5000 UV-Vis (Quawell). TaqMan assays for $\mathrm{rAAV}$ genome copy number were developed using probe and primers for the ITR region. The fluorescent probe (5'-CACTCCCTCTCTGCGCGCTCG-3') featured 6-FAM and TAMRA. The forward primer was 5'-GGA ACCCCTAGTGATGGAGTT-3' and the reverse primer was 5'-CGGCCTCAGTGAGCGA-3' (36). Total volume of qPCR reactions was $10 \mu \mathrm{l}$, contained $50 \mathrm{ng}$ DNA and ran under the following conditions: $50^{\circ} \mathrm{C}$ for $2 \mathrm{~min}, 95^{\circ} \mathrm{C}$ for $10 \mathrm{~min}$, 40 cycles of $95^{\circ} \mathrm{C}$ for $15 \mathrm{sec}$ and $60^{\circ} \mathrm{C}$ for $60 \mathrm{sec}$. qPCR was performed in StepOnePlus ${ }^{\mathrm{TM}}$ Real-Time PCR System (Applied Biosystems; Thermo Fisher Scientific, Inc.). Absolute quantification analysis with the StepOne Software v2.3 (Thermo Fisher Scientific, Inc.) was performed to determine transcripts numbers. Data were quantified using the standard curve (37, 38). Briefly, standard curves were generated using serial dilutions of plasmid pAAV-hrGFP (Agilent Technologies) used to calculate the number of genome copies in the tested samples. The rAAV genome copy number was normalized as viral genome copy number per $50 \mu \mathrm{g}$ of total genomic DNA.

Reverse transcription qPCR. To test gene expression, total RNA was isolated (39) using the TRI Reagent (Sigma-Aldrich; Merck KGaA). To examine the miRNA profile, RNA was isolated with the used of the TRIzol (Invitrogen; Thermo Fisher Scientific, Inc.). DNA-free ${ }^{\mathrm{TM}}$ DNA Removal Kit (Invitrogen; Thermo Fisher Scientific, Inc.) was used to remove the contaminating DNA from RNA samples. Single-stranded cDNA was synthesized with the High Capacity RNA-to-cDNA kit (Applied Biosystems; Thermo Fisher Scientific, Inc.). All primers listed below are available on Thermo Fisher Scientific website as appropriate TaqMan Assays (Thermo Fisher Scientific Website; https://www.thermofisher.com/pl/en/home. html).

The expression of genes-encoding receptors for AAV was examined with the use of the following TaqMan Assays (assay ID; Thermo Fisher Scientific, Inc.): AAVR (Hs00967343_m1), HSPG1 (Hs01081432_m1), HSPG2 (Hs01078536_m1), and ACTB (Hs01060665_g1) as endogenous control. The expressions were measured after $24 \mathrm{~h}$ from exposure at 40 and $43^{\circ} \mathrm{C}$ for $3 \mathrm{~h}$. The ovarian cancer cells, AAV-293 and CCD-18Co were used. CCD-18Co was selected as a reference sample in $\Delta \Delta$ Cq method (37).

The expression of miRNA responsible for silencing AAVR, HSPG1 and HSPG2 was examined on the designed TaqMan Custom MiRNA Array Card (TaqMan Low-Density Array-TLDA card; Thermo Fisher Scientific, Inc.) for Caov-3, NIH:OVCAR-3 and AAV-293 cell lines maintained in normal culture condition. The following human miRNA were analyzed (assay ID, Thermo Fisher Scientific): miR-15b-5p (000390), miR-133a-3p (002246), miR-195-5p (000494), miR-23a-3p (000399), miR-23b-3p (000400), miR-27a-3p (000408), miR-30a-5p (000417), miR-34a-5p (000426), miR-34c-5p (000428), miR-101-3p (002253), and U6 snRNA (001973). Functional links between the designated miRNAs and the AAVR, HSPG1 and HSPG2 genes were searched in miRNA databases $(40,41)$.

The expression of HSP was examined on TaqMan Array 96-Well FAST Plate Human Heat Shock Proteins (cat. no. 4418733; Applied Biosystems; Thermo Fisher Scientific, Inc.) in ovarian cancer cells $24 \mathrm{~h}$ after exposure to hyperthermia condition. Results for cells maintained at $37^{\circ} \mathrm{C}$ were selected as reference samples and used for the comparison of constitutive levels of HSP in ovarian cancer cell lines.

The expression of genes associated with the molecular mechanisms of cancer was examined on TaqMan Array 96-Well FAST Plate Human Molecular Mechanisms of Cancer (MMoC; cat. no. 4418806; Applied Biosystems; Thermo Fisher Scientific, Inc.) for Caov-3 and NIH:OVCAR-3 maintained in normal culture condition.

In all gene expression tests total volumes of qPCR reactions were $10 \mu \mathrm{l}$, contained $100 \mathrm{ng} \mathrm{cDNA}$ and ran under the following conditions: $50^{\circ} \mathrm{C}$ for $2 \mathrm{~min}, 95^{\circ} \mathrm{C}$ for $10 \mathrm{~min}, 40$ cycles of $95^{\circ} \mathrm{C}$ for $15 \mathrm{sec}$ and $60^{\circ} \mathrm{C}$ for $60 \mathrm{sec}$. The FAM was used as fluorophore and NFQ-MGB as a quencher (Thermo Fisher Scientific, Inc.). Transcript levels of target genes were normalized to the level of housekeeping genes encoding: $\beta$-actin (ACTB) for AAV 
receptors, U6 snRNA for miRNA, $\beta$-glucuronidase (GUSB) and hypoxanthine phosphoribosyltransferase 1 (HPRT1) for HSP and glyceraldehyde-3-phosphate dehydrogenase (GAPDH) for MMoC. All reactions were performed according to manufacturer instructions in the StepOnePlus ${ }^{\mathrm{TM}}$ Real-Time PCR System. Relative gene expression levels were calculated using the $\Delta \Delta \mathrm{Cq}$ method (37) by Expression Suite Software v1.1 (Thermo Fisher Scientific, Inc.). The Morpheus matrix visualization and analysis software was used to present results of miRNA and MMoC expression as heat maps (in the form of $2^{-\Delta \mathrm{Ct}}$ ) (Morpheus-versatile matrix visualization and analysis software; https://software.broadinstitute.org/morpheus).

Protein CA 125 measure. To measure the level of CA 125 marker, Caov-3, NIH:OVCAR-3 and AAV-293 cells were harvested, washed with PBS and lysed in lysis RIPA buffer [10 mM Tris- $\mathrm{HCl}$ (pH 7.5), $150 \mathrm{mM} \mathrm{NaCl,} \%$ NP-40, 0,5\% Sodium Deoxycholate, $0,1 \%$ SDS and protein inhibitor cocktail (cat. no. P8340; Sigma-Aldrich; Merck KGaA)] for 30 min on ice. The probes were centrifuged $\left(20 \mathrm{~min}, 4^{\circ} \mathrm{C}, 12,500 \mathrm{rpm}\right)$, and the supernatants were collected for further tests. CA 125 was measured in protein samples using solid phase, two-site sequential chemiluminescent assays (CLIA) with paramagnetic microparticle solid phase that was fully processed on an automated randomaccess immunoassay analyzer LIAISON XL (DiaSorin, Saluggia, Italy). The intra- and interassay CV for CA 125 ranged from 1.4-2.2 and 4.6-5.8\%, respectively.

Cell adhesion. The adhesion potency of the tested cells was determined using laminin coated plates (cat. no. 354404; 6-well plates; BD BioCoat ${ }^{\mathrm{TM}}$ Laminin). The experiment was performed for transduced and non-transduced cells incubated at a different temperature $\left(37,40,43^{\circ} \mathrm{C}\right)$. The examined cell lines on the 6th day after transduction were trypsinized (Trypsin-EDTA $(0.25 \%)$, phenol red; Gibco; Thermo Fisher Scientific, Inc.), counted (in an automatic cell counter) and seeded on laminin plates. From a $6 \mathrm{~cm}$ diameter dish, the cells were transferred to 1 well in laminin coated plate. A control was performed, i.e., cells were seeded on 6-well plates without laminin (Nunc; Thermo Fisher Scientific, Inc.). After $4 \mathrm{~h}$ of incubation under standard culture conditions, the attached cells were trypsinized and the number of viable cells was counted. Subsequently, the percentage of adhered cells was estimated due to laminin presence.

Invasion chamber assay. To verify how hyperthermia and transduction modify cell invasion, invasion chamber assay was performed using a 24-well cell culture insert $8 \mu \mathrm{m}$ pore (cat. no. 354480; Corning Matrigel Invasion Chamber; Corning). The examined cell lines on the 6th day after transduction were trypsinized, cell suspensions in $2 \%$ FBS media at a concentration of $1 \times 10^{5} / \mathrm{ml}$ for AAV-293, Caov-3 and $1.5 \times 10^{5} / \mathrm{ml}$ for NIH: OVCAR-3 were prepared. Cell suspensions in volume $0.5 \mathrm{ml}$ were added per well into the upper chambers, the lower chambers were filled with $0.5 \mathrm{ml}$ of complete media. Cells which migrated to the lower chamber were counted after 24 and $48 \mathrm{~h}$. The cells from the upper membrane were aspirated by gentle pipetting. The GFP+ cells from the bottom side of the Matrigel chamber were visualized with the fluorescence microscope (with FITC) after $24 \mathrm{~h}$.
After $48 \mathrm{~h}$ of incubation, cells which migrated to the bottom of the Matrigel surface were fixed with methanol and stained with $0.5 \%$ crystal violet.

Statistical analysis. The transduction efficiency, receptor expression (AAVR, HSPG1, HSPG2), cell adhesion and cell invasion results expressed as mean and standard deviation. HSP results were performed as mean and standard error. A one-way analysis of variance (ANOVA, $\alpha=0.05$ ) with a post-hoc Bonferroni $(\alpha=0.05)$ test using GraphPad Prism 7 (GraphPad Software, La Jolla, CA, USA) was used to calculate the statistical significance of differences between mean values of compared samples. $\mathrm{P}<0.05$ was considered to indicate a statistically significant difference.

\section{Results}

rAAV transduction of ovarian cancer cells at hyperthermia conditions. The effect of elevated temperature on rAAV transduction was investigated using ovarian carcinoma cell lines of different clinical origin and pathomechanism of carcinogenesis. The NIH:OVCAR-3 cell line was originally derived from the malignant ascites of a patient with progressive adenocarcinoma of the ovary. NIH:OVCAR-3 cells are resistant to cytostatics at concentrations used in clinics and they are sensitive to hormonal therapy (32). Caov-3 cells are derived from the ovarian solid tumor (33). The cells' functional variability was visualized through the analysis of the expression of Molecular Mechanisms of Cancer (MMoC) genes that are essential for carcinogenesis. The MMoC gene expression pattern of functionally differentiating ovarian cancer lines is shown in Table I and Fig. 1. Ascites-derived NIH:OVCAR-3 cells were characterized by a higher expression of almost all genes involved in proliferation, cell cycle, cell differentiation, metastasis, invasion, angiogenesis, apoptosis and signal transduction processes, than the solid-derived Caov-3 cells (Table I). Additionally, the estimated ovarian cancer marker CA 125 confirmed the origin of ovarian cancer cells, as well provided information about the protein expression in the studied cells. CA 125 is a tumor marker, which is mainly used in the diagnosis of ovarian cancer and monitoring treatment. As shown in Table II, the level of CA 125 for NIH:OVCAR-3 and Caov-3 was $>68,590.0$ and 2,220.0 U/ml, respectively. In the case of control line AAV-293, marker was determined on the level $<0.3 \mathrm{U} / \mathrm{ml}$. The obtained results showed that ascites-derived NIH:OVCAR-3 cells were characterized by increase expression of this cancer marker, which may indicate a higher invasiveness and progress in carcinogenesis of this line, compared to Caov-3 derived from a solid tumor.

Transductions were carried out under conditions of 37 , 40 and $43^{\circ} \mathrm{C}$, defined as hyperthermia conditions (21). To determine the transcriptional activity of the CAG and $\mathrm{cmv}$ promoters, the cells were transduced with the rAAV/DJ mosaic vector with the GFP reporter gene under the control of the hybrid CAG promoter (AAV-293) or the conventional cmv promoter (Caov-3 and NIH:OVCAR-3). The transduction efficiency was determined by direct counts of GFP+ cells and measuring genome copies of rAAV in transduced cells with qPCR. As Fig. 2A shows, as the temperature 
Table I. Expression of representative genes involved in cancer.

\section{NIH:OVCAR-3}

\begin{tabular}{|c|c|c|c|c|}
\hline $\begin{array}{l}\text { Fold change } \\
\left(2^{-\Delta \Delta C q}\right)\end{array}$ & $\begin{array}{c}\text { Proliferation, cell cycle, } \\
\text { cell differentiation }\end{array}$ & $\begin{array}{l}\text { Metastasis, invasion, } \\
\text { angiogenesis }\end{array}$ & Apoptosis & Signal transduction \\
\hline 0.00 & & CDC42, ITGB3, COL1A1 & BCL2 & KIT \\
\hline$<0.50$ & $\begin{array}{l}\text { TGFB1 CCND3, } \\
\text { CDKN1A }\end{array}$ & & & FDZ1 \\
\hline $0.51-1.00$ & $\begin{array}{l}\text { EGFR JUN, CCND1, } \\
\text { CDK2 }\end{array}$ & $\begin{array}{l}\text { FYN, ITGB1, SPP1, } \\
\text { VEGFA }\end{array}$ & BID & $\begin{array}{l}\text { FAS, IGF1R, MAP2K1, PIK3CA, } \\
\text { SHC1 }\end{array}$ \\
\hline $1.01-1.50$ & ELK1, FGF2 MYC & & BAX, FADD & $\begin{array}{l}\text { AKT1, MAPK1, NFKB2, NRAS, } \\
\text { RAC1 }\end{array}$ \\
\hline $1.51-2.00$ & FOS BCAR1, PTEN & & & RAF1, MAPK8 \\
\hline $2.01-2.50$ & & PTK2B & & $\begin{array}{l}\text { MAP3K5, MAPK14, MAPK3, } \\
\text { NFKB1, RELA, SMAD4, SOS1 }\end{array}$ \\
\hline $2.51-3.00$ & MDM2 & CRK, RHOA & $\begin{array}{l}\text { BCL2L1, } \\
\text { CASP8, GSK3B }\end{array}$ & ERBB2, GRB2, TGFBR2 \\
\hline $3.01-4.00$ & TCF3 CDH1, E2F1 & CTNNB1, ITGAV & & APC, BRAF, TGFBR1 \\
\hline $4.01-5.00$ & DVL1 CDKN1B & FN1 & BCL2L11 & HRAS, NFKBIA, PTK2 \\
\hline $5.00-10.00$ & $\begin{array}{l}\text { ABL1, SRC CDK4, } \\
\text { CDKN2A }\end{array}$ & ITGA2B & CYCS & \\
\hline $10.01-15.00$ & CCNE1 & & & AKT2, PIK3R1 \\
\hline $15.01-50.00$ & CDKN2B & & & KRAS \\
\hline $50.01-300.00$ & TP53 & & & LEF1 \\
\hline$>300.01$ & RB1 & & & IGF1 \\
\hline
\end{tabular}

The molecular status of two ovarian cancer cell lines of different origin are presented. The expression of genes involved in cell proliferation, the cell cycle, cell differentiation, metastasis, invasion, angiogenesis, apoptosis and signal transduction were presented as $2^{-\Delta \Delta \mathrm{Cq}}$ values, with Caov-3 as a reference.

elevates, the transduction efficiency increases. Furthermore, there were differences in the transduction efficiency between the lines. The highest efficiency of transduction was demonstrated for NIH:OVCAR-3 cells. At $37^{\circ} \mathrm{C}$, approximately $23 \%$ of cells were GFP+. In comparison only $2 \%$ of Caov-3 cells, and $6 \%$ of AAV-293 cells under the same conditions were transduced. The temperature effect was visible for all lines. As the temperature raised, the percentage of GFP+ cells increased significantly. Despite the lower level of transduction efficiency, Caov-3 cells responded to temperature stimulation in both 40 and $43^{\circ} \mathrm{C}$. In $40^{\circ} \mathrm{C}$, a $50 \%$ increase in $\mathrm{GFP}+$ cells was observed, and in $43^{\circ} \mathrm{C}$, GFP+ cells showed an increase of $200 \%$ compared to $37^{\circ} \mathrm{C}$. The percentage of fluorescent NIH:OVCAR-3 cells was significantly increased in $40^{\circ} \mathrm{C}$ (about $65 \%$ compared to normal temperature; Fig. 2A).

The transduction efficiency was also determined by the qPCR method (Fig. 2B). The percentage of GFP+ cells corresponds to the number of rAAV genome copies $(\mathrm{gc})$ in all transduced cells. As shown in Fig. $2 \mathrm{~B}$, at $40^{\circ} \mathrm{C}$ a higher level of gc was demonstrated than at $37^{\circ} \mathrm{C}$, which reflects the increase in transduction efficiency due to response to the rise in temperature. Interestingly, at $43^{\circ} \mathrm{C}$ an increase in the number of GFP+ cells was observed, with the gc number in all lines being lower than at $40^{\circ} \mathrm{C}$ and even $37^{\circ} \mathrm{C}$ (Fig. 2B).
$A A V$ receptor expression. The expression of crucial genes of the extracellular rAAV transmission was analyzed in the study. The AAVR, HSPG1 and HSPG2 genes were selected for evaluation. The qPCR method was determined by normalizing the results to the level of ACTB gene expression, the human fibroblasts (CCD-18Co cells) were used as reference. As shown in Fig. 3, the expression of the examined genes changes with increasing temperature. Additionally, the expression pattern for AAVR, HSPG1 and HSPG2 genes was different in the lines tested. In NIH:OVCAR-3 cells, AAV receptor signature was revealed as a high expression of AAVR and HSPG1, and as a low expression of HSPG2. On the other hand in Caov-3 cells, the signature of selected genes occurred as a comparable expression level of all three genes tested. However, the expression of AAVR dominated in AAV-293 cells. Expression of receptors in NIH:OVCAR-3 ovarian cancer cells was higher than in Caov-3 cells at 37, 40, and $43^{\circ} \mathrm{C}$, which corresponds with the higher transduction efficiency in NIH:OVCAR-3 (Fig. 2). Caov-3 cells, despite lower expression of AAV receptors, respond better to the increase of temperature. The expression of AAVR, HSPG1 and HSPG 2 at $40^{\circ} \mathrm{C}$ has increased by 29,51 and $82 \%$ respectively, compared to $37^{\circ} \mathrm{C}$. In the case of AAVR and HSPG1 after $43^{\circ} \mathrm{C}$, the expression normalized to the level observed in $37^{\circ} \mathrm{C}$, but for HSPG2 the expression remained at a level 


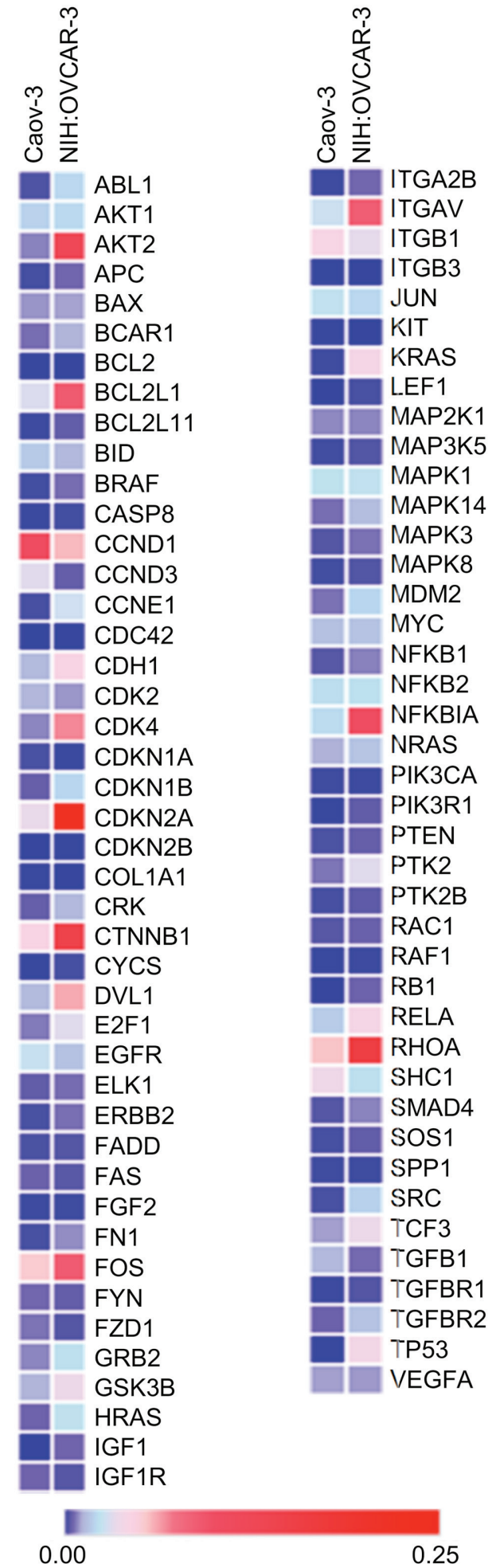

Figure 1. Heat map of the representative gene expression $\left(2^{-\mathrm{ACq}}\right)$ revealed in two ovarian cancer cell lines of different origin.

similar to $40^{\circ} \mathrm{C}$. For NIH:OVCAR-3 cells, there was an increase in AAVR expression in $43^{\circ} \mathrm{C}$ of about $5 \%$ and HSPG2 of about $33 \%$, vs. $37^{\circ} \mathrm{C}$. The most proportional increase in the expression of AAVR and HSPG1 to the temperature elevation was observed for AAV-293 cells. They responded with the increase of AAVR and HSPG1 by approx. $6,7 \%$ at $40^{\circ} \mathrm{C}$, and 37 and $92 \%$ at $43^{\circ} \mathrm{C}$, respectively. Interestingly, despite an increase in the number of GFP+ cells (Fig. 2A), a lower
Table II. CA 125 protein levels in AAV-293, Caov-3 and NIH:OVCAR-3 cell lines.

\begin{tabular}{lc}
\hline Cell lines & CA $125(\mathrm{U} / \mathrm{ml})$ \\
\hline AAV-293 & $<0.3$ \\
Caov-3 & $2,220.0$ \\
NIH:OVCAR-3 & $>68,590.0$
\end{tabular}

level of receptor expression as well as the rAAV copy number was observed in cells exposed to $43^{\circ} \mathrm{C}$ (Fig. 2B).

miRNA expression panel. During the search for mechanisms to increase the efficiency of rAAV transduction in cells exposed to elevated temperature, particular attention was paid to the expression of selected miRNAs. MiRNAs involved in the silencing processes of rAAV transmission were analyzed. Fig. 4B shows the mean expression of silencing miRNAs in the cells tested at $37^{\circ} \mathrm{C}$ and indicates that the level of miRNA corresponds to the rAAV transduction efficiency. The mean values were calculated due to underline the miRNA expression differences between studied cell lines. The lowest level of miRNAs responsible for silencing AAV transmission genes was observed for NIH:OVCAR-3. This ovarian cancer cell line was transfected at the highest level. The level of silencing miRNAs was about 35\% higher in Caov-3 cells which transduced almost 12 times less efficiently than NIH:OVCAR-3. In the case of AAV-293 cells there was no functional coherence between the miRNA level and the transduction efficiency. The level of miRNA in AAV-293 cells was about $60 \%$ lower than in NIH:OVAR-3, although the AAV-293 transduction efficiency (Fig. 2A) was lower than NIH:OVCAR-3.

HSP expression. The result of HSPs expression in NIH:OVCAR-3 and Caov-3 ovarian cancer cells are shown in Figs. 5 and 6. Fig. 5 shows the constitutive level of HSP expression in lines at $37^{\circ} \mathrm{C}$, expressed in $2^{-\Delta \mathrm{Cq}}$ form, while Fig. 6 shows changes in HSP level $\left(2^{-\Delta \Delta \mathrm{Cq}}\right.$, fold range) in cells exposed to elevated temperature $\left(40\right.$ and $\left.43^{\circ} \mathrm{C}\right)$. As shown in Fig. 5, in NIH:OVCAR-3 22 out of 42 HSP genes tested had higher expression than in Caov-3 cells. NIH:OVCAR-3 cells compared to Caov-3 are characterized by higher expression of the HSP40 family (DNAJA2, DNAJB13, DNAJB2, DNAJB4, DNAJC7), HSP90 family (HSP90AA1, HSP90B1), and HSP70 family (HSPA14, HSPA1A, HSPA1L, HSPA4, HSPA4L, HSPA6). NIH:OVCAR-3 cells also had a higher expression of HSP than Caov-3: AHSA1, HSPB8, HSPB9, HSPBAP1, HSPD1, HSPE1, STUB1, and TRAP1. Based on the highest expression HSP (3-10x higher than in Caov-3), the form of AHSA1+, HSP90AA1+, HSPA1A+, HSPD1+, STUB1+, and TRAP1+ can be proposed as constitutive signature for NIH:OVCAR-3 cells. On the other hand, the characteristic HSP signature for Caov-3 (3-10x higher HSP levels than in NIH:OVCAR-3) is DNAJB1+, HSP90AB1+, HSPA5+, HSPA8+, and HSPB1+. The obtained results (Fig. 5) may explain the differences between the NIH:OVCAR-3 and Caov-3 cell lines in the transduction efficiency (Fig. 2). Results presented in Fig. 6 show that the selected hyperthermia conditions caused the increase of 
A

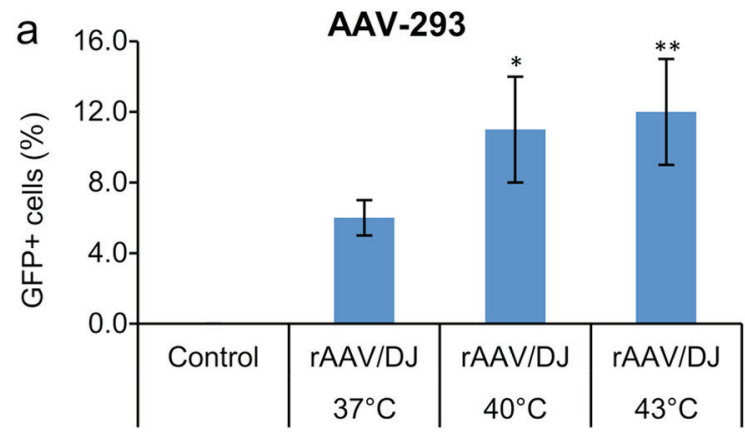

C
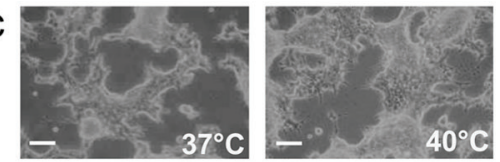

AAV-293 - Control

B

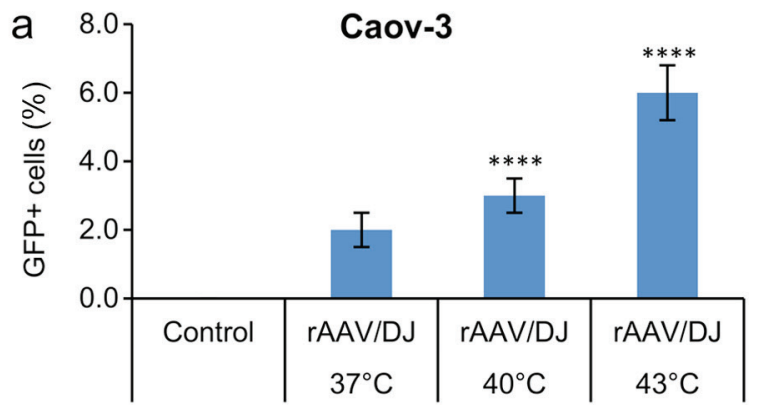

C
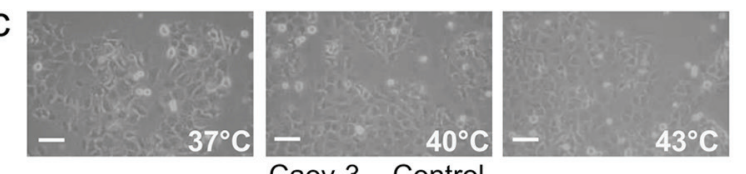

C a
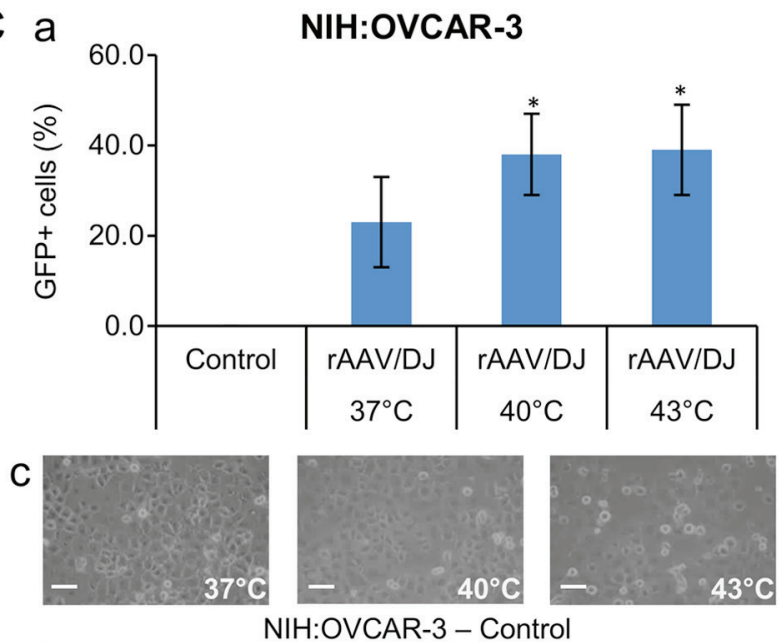
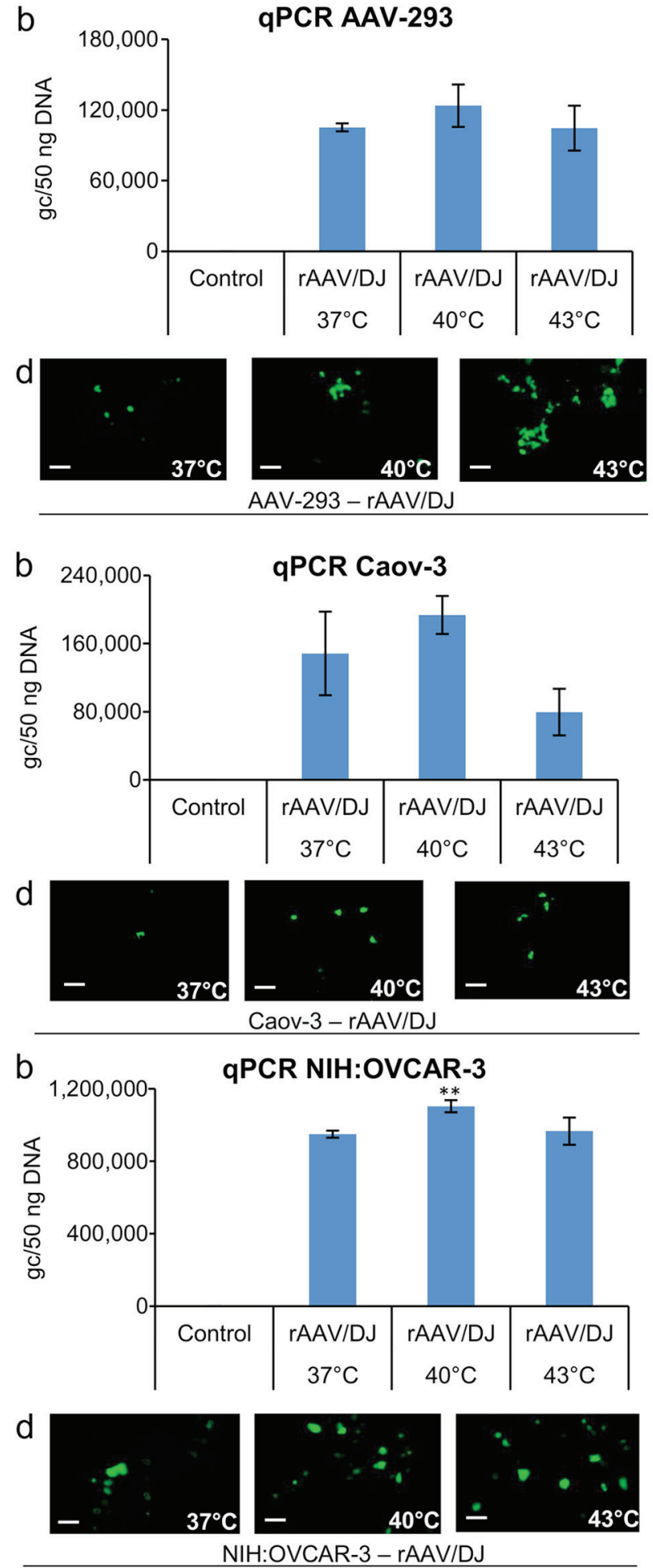

Figure 2. Transduction efficiency of AAV-293, Caov-3 and NIH:OVCAR-3 cells. (A) AAV-293, (B) Caov-3 and (C) NIH:OVCAR-3 cells were transduced with the rAAV/DJ vector under normal $\left(37^{\circ} \mathrm{C}\right)$ and hyperthermic conditions $\left(40\right.$ and $\left.43^{\circ} \mathrm{C}\right)$ for $3 \mathrm{~h}$. The green fluorescent protein positive cells were analyzed using (a) the Countess II FL Automated Cell Counter, (b) qPCR and visualized with an inverted fluorescence microscope under (c) bright field and (d) FITC (magnification, $\mathrm{x} 10$; scale bar, $100 \mu \mathrm{m})$. Results are presented as the mean \pm standard deviation. ${ }^{*} \mathrm{P}<0.05,{ }^{* * *} \mathrm{P}<0.01$ and ${ }^{* * * * *} \mathrm{P}<0.0001 \mathrm{vs} .37^{\circ} \mathrm{C}$. rAAV/DJ, recombinant adeno-associated viral hybrid serotype DJ; qPCR, quantitative PCR.

selected HSP expression. NIH:OVCAR-3 cells demonstrated an increase expression at 40 and $43^{\circ} \mathrm{C}$ for AHSA1, DNAJA3, DNAJB2, DNAJC3, HSP90AA1, HSPA2, HSPA5, HSPA6, and HSPB1 (Fig. 6). A particularly high ( $>10 x)$ increase in expression for DNAJB13, HSPA6, and HSPB1 was observed. Caov-3 cells were much less responsive to hyperthermia through increased HSP expression (Fig. 6). Of the 42 HSP genes examined, only 5 genes showed increased expression at elevated temperature (DNAJB2, HSPA1L, HSPB1, HSPB6, HSPBAP1). In conclusion, the various ovarian cancer cells responded significantly differently to both the constitutive HSP expression level at $37^{\circ} \mathrm{C}$ and after the exposure cells to 


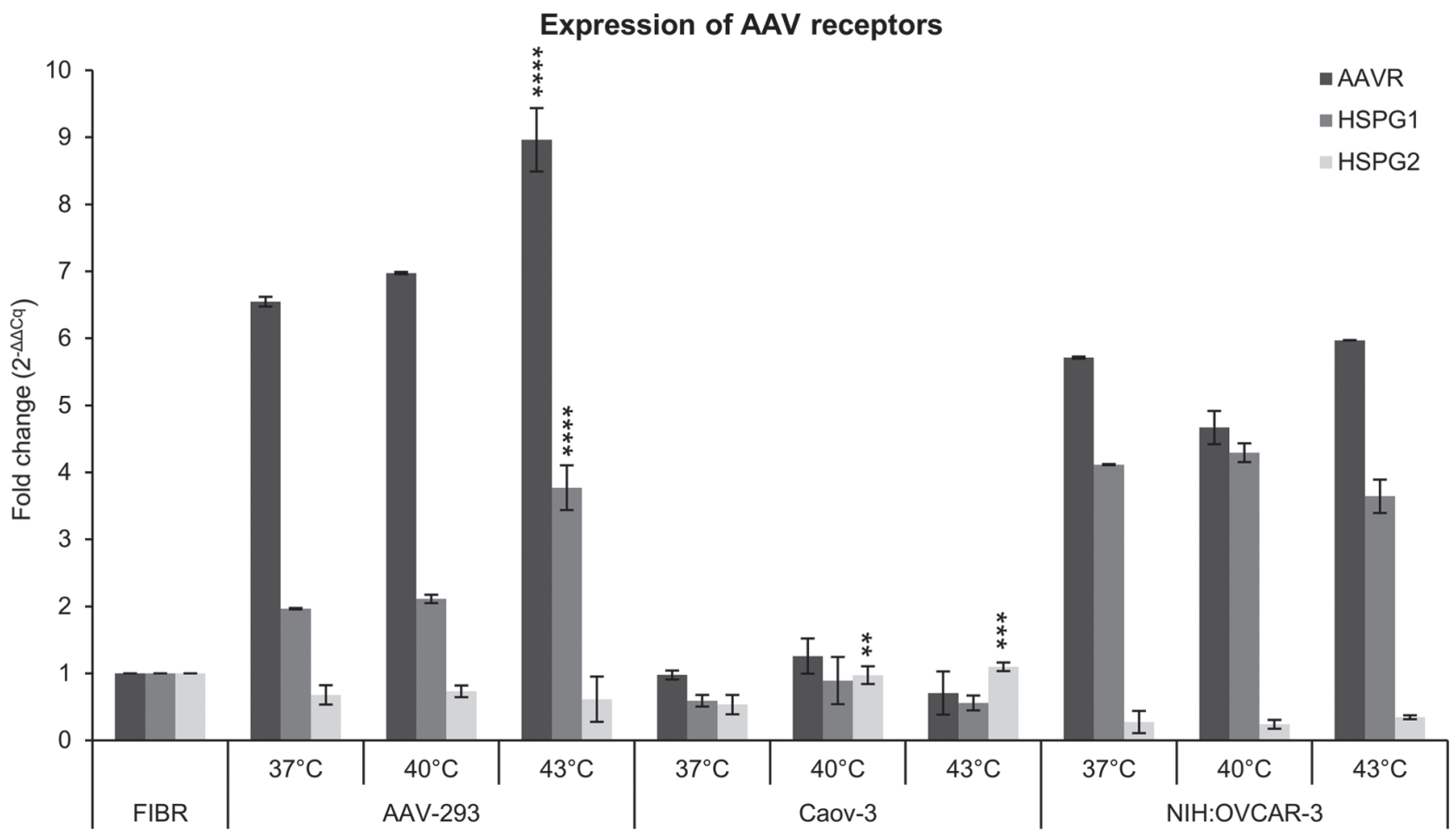

Figure 3. AAVR, HSPG1 and HSPG2 expression in AAV-293, Caov-3 and NIH:OVCAR-3 cells. The influence of heat shock on the expression of genes in ovarian cancer cells and normal cells was determined via reverse transcription-quantitative PCR. The CCD-18Co fibroblast cell line was used as reference to calculate fold change $\left(2^{-\Delta \Delta C q}\right)$. Data are presented as the mean \pm standard deviation. ${ }^{* *} \mathrm{P}<0.01,{ }^{* * * *} \mathrm{P}<0.001$ and ${ }^{* * * *} \mathrm{P}<0.0001$ vs. $37^{\circ} \mathrm{C}$. AAVR, adeno-associated virus receptor; HSPG, heparin sulfate proteoglycan.
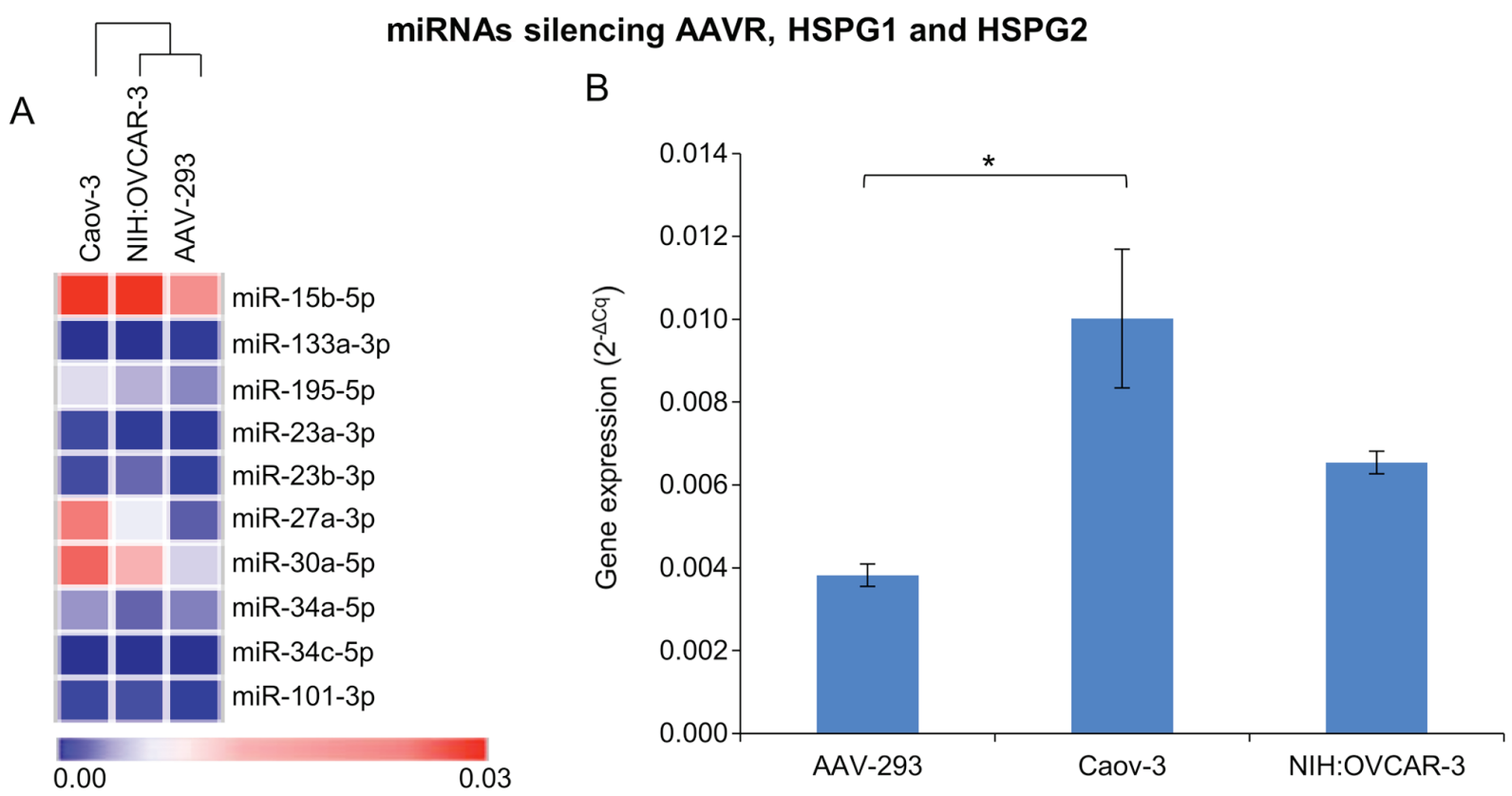

Figure 4. AAV-293, Caov-3 and NIH:OVCAR-3 cell miRNA analysis at normal temperatures. The selected miRNA responsible for silencing the cell transmission genes of rAAV (AAVR, HSPG1 and HSPG2) were assessed via reverse transcription-quantitative PCR. (A) Heat map represents the $2^{-\triangle C q}$ data obtained from the studied miRNA. The distance clustering of the examined cells was elucidated. (B) Mean value of all analyzed miRNAs $\left(2^{-\Delta C q}\right)$ characteristic of AAV-293, Caov-3 and NIH:OVCAR-3 cell lines. Mean values were calculated to better visualize the miRNA expression differences between studied cell lines. Data are presented as the mean \pm standard deviation. "P $<0.05$ as indicated. miRNA, microcRNA; rAAV, recombinant adeno-associated viruses; AAVR, adeno-associated virus receptor; HSPG, heparin sulfate proteoglycan;

40 and $43^{\circ} \mathrm{C}$. Temperature-dependent changes in HSP expression appear to be helpful to understand the rAAV transduction efficiency increase in cells exposed to elevated temperature.
Cell adhesion. To investigate the influence of rAAV transduction and hyperthermia on the biology of the studied cells, adhesion assays were performed. The cells were 


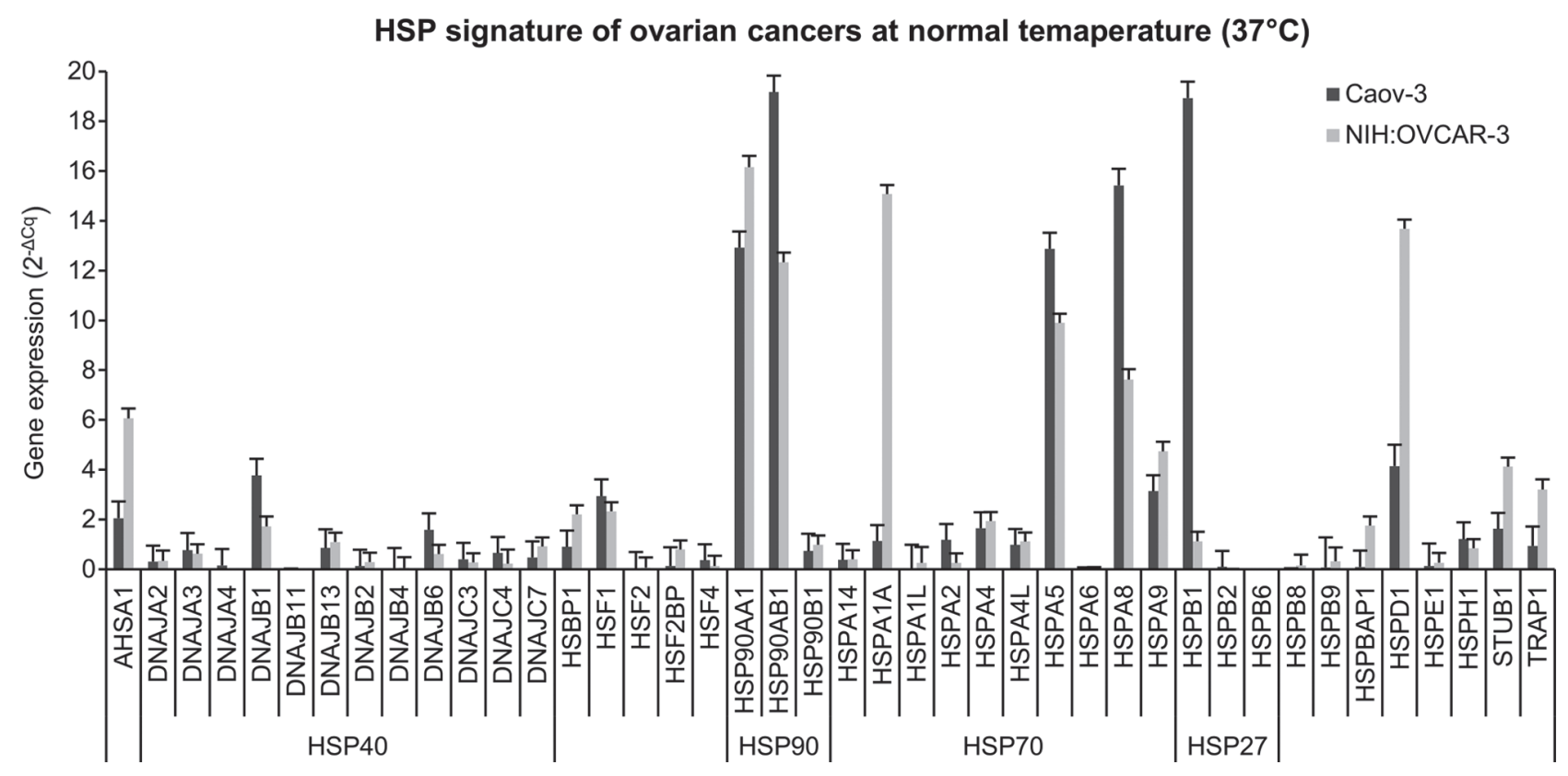

Figure 5. HSP expression profiles of ovarian cancer in Caov-3 and NIH:OVCAR-3 cell lines at $37^{\circ} \mathrm{C}$. Relevant differences between constitutive expressions of HSP $\left(2^{-\Delta \mathrm{Cq}}\right)$ are presented. Data are presented as the mean $\pm \mathrm{SE}$. HSP, heat shock protein.

plated on dishes covered with laminin which is described as crucial protein for extracellular matrix maintenance. Generally, as shown in Fig. 7, the greater number of cells attached to the control plates (without laminin) was noted. The results demonstrated that hyperthermia induced the decrease of the number of adhered cells. In the case of AAV-293 line, in plate without extracellular matrix protein were small differences in the percentage of viable, adherent cells for each temperature. Whereas, for the ovarian cancer cell lines a decrease in attached cells exposed to hyperthermia was observed for both panels, with and without laminin. Additionally, the NIH:OVCAR-3 cell line showed the lowest adhesion potency after incubation at $43^{\circ} \mathrm{C}$. The control AAV-293 cells were characterized by a greater ability to adhere compared to ovarian cancer cells. In all the tested cell lines no effect of rAAV/DJ transduction for adhesion was observed.

Invasion chamber assay. To determine how transduction and hyperthermia can change the invasiveness od tested cells, Matrigel chamber assays were performed. The invasive cells were counted, and crystal violet stained. Results presented on Fig. 8 showed that hyperthermia increased the invasiveness of all tested cells in both groups (transductants and non-transductants) in temperature-dependent manner. The highest cell numbers in the lower chambers were observed at $43^{\circ} \mathrm{C}$. Moreover, the NIH:OVCAR-3 was indicated as the most invasive cell line. The non-cancerous AAV-293 line revealed the lowest number of cells which pass through the chamber membrane. Number of the cells migrated to the lower chamber through the Matrigel, collected after 24 and $48 \mathrm{~h}$ were similar, which may indicate significant changes in cellular physiology that occurred after incubation at hyperthermia. The rAAV/DJ transduction did not affect the invasive potential of the examined cells.

\section{Discussion}

As we read in one of the last issues of the prestigious journal Science (42), gene therapy, thanks to translational research, is strengthening its position in clinical trials. The authors of the review, leaders in the field of gene therapy, conclude that clinical trials, which started in the 1990 with varying degrees of success, enabled that gene therapy to now play a significant role in medicine thanks to advanced basic and translational research. The authors of the Science article emphasize the main, extremely crucial solutions in the field of DNA vectorology, which form the basis for the development of gene therapy. Moreover, researchers suggest further advances in gene therapy will be determined by three approaches. These are strategies based on rAAV vectorology, lenivirus vectors and gene editing technologies (42). In each of these strategies, intensive research is conducted to increase the efficiency of transduction and in vivo selectivity, and to reduce side effects. Research aimed at optimizing the dose of used viral vectors is important. Having the tools to reduce the doses of the vectors used, while maintaining high efficiency of gene transfer, will lead to increase in the biosafety of viral vectorology and consequently facilitate the introduction of viral vectors to patients. The use of physicochemical solutions in gene transfer methods is gaining attention. One of the approaches is the use of physical factors, such as temperature, $\mathrm{pH}$, light, sounds for precise activation/deactivation of gene expression and to improve the efficiency of transduction (19).

Recently observed interest in using temperature for gene therapy purposes is partly due to the development of innovative, oncological patient treatment methods based on temperature modulation. The hyperthermia described in the literature assumes local or comprehensive (whole body) heating of tissues to produce a therapeutic effect. Hyperthermia is primarily considered a therapeutic strategy 

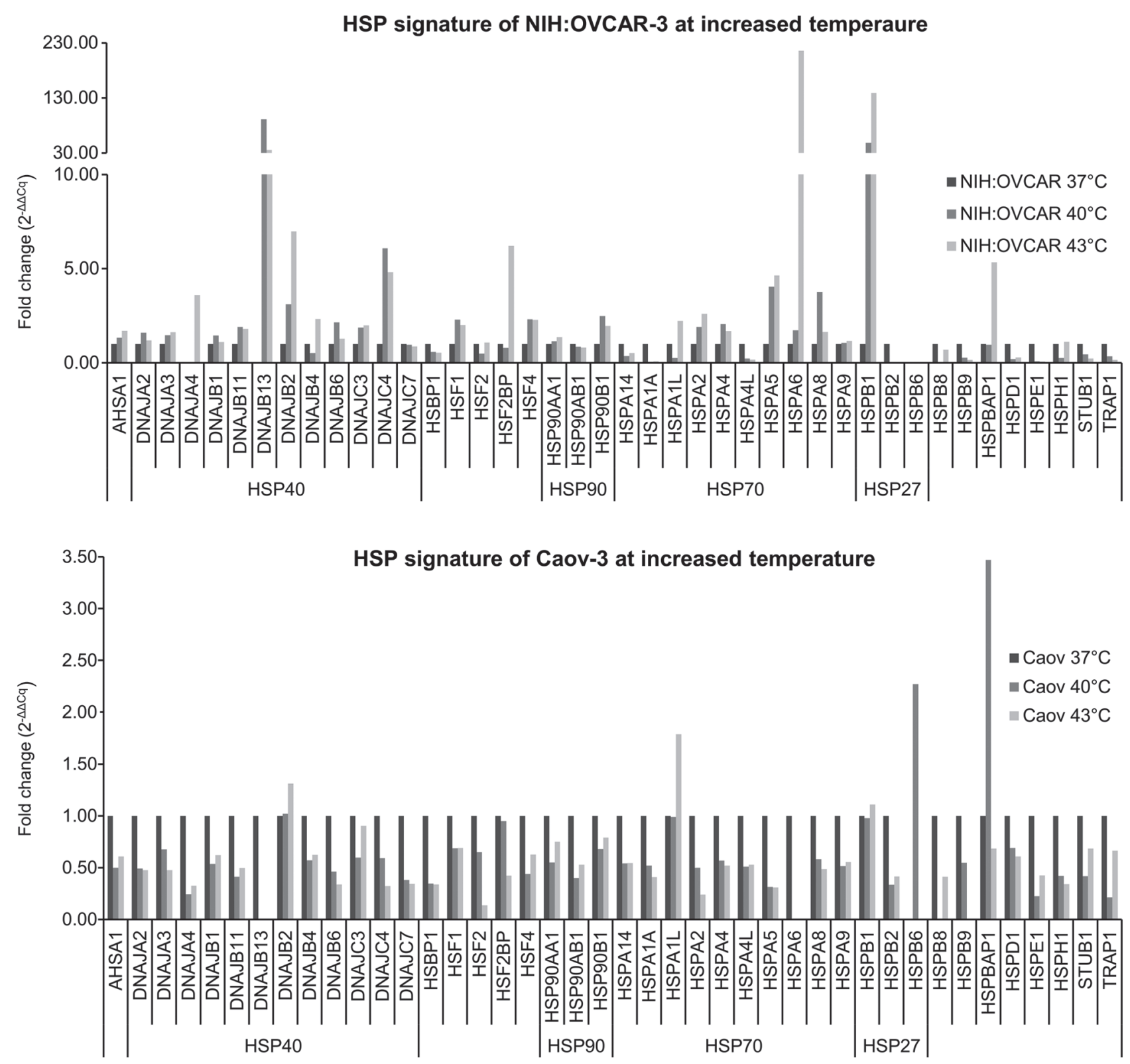

Figure 6. Temperature-associated HSP expression profiles of ovarian cancer cell lines (Caov-3 and NIH:OVCAR-3). Cells were exposed to hyperthermic conditions $\left(40\right.$ and $\left.43^{\circ} \mathrm{C}\right)$. Under heat shock conditions, differences were revealed between the sensitivity of ovarian cancer cells to increased temperature. Expression values $\left(2^{-\Delta \Delta C q}\right)$ indicate the specific HSP signature for ovarian cancers of different origin. Samples at $37^{\circ} \mathrm{C}$ were not exposed to hyperthermic conditions and were used as reference to calculate fold change $\left(2^{-\Delta \Delta C q}\right)$. HSP, heat shock protein.

complementing or supporting classical protocols of oncological treatment (21). In addition to the direct cytotoxic effect on cancer cells, the influence of hyperthermia to vascular permeability and drug penetration is highlighted $(19,21)$. In the field of oncological hyperthermia, an interesting solution is Hyperthermic Intraperitoneal Chemotherapy-HIPEC. The importance of HIPEC in the treatment of intraperitoneal dissemination of tumors originating from the gastrointestinal tract and the female genital organs, including ovarian cancer, is emphasized $(22,43,44)$. Individual selected cytostatics (e.g., mitomycin $\mathrm{C}$, doxorubicin, cisplatin) administered to oncological patients by perfusion under elevated temperature (hyperthermia conditions; e.g., $\left.0.5-1.5 \mathrm{~h}, 41-43^{\circ} \mathrm{C}\right)(43)$ may significantly increase the patients' lifetime $(22,44)$. The use of hyperthermia in clinics may be associated with some complications. Generally, healthy tissues are not destroyed during hyperthermia. The differences into tissue characteristics implicate to the changes between heat distribution in patient's body. This may result in burns, discomfort or pain. Complications associated with the method of achieving high temperature of tissue, in the case of perfusion techniques may appear tissue swelling, blood clots, bleeding, and other damage in the perfusion area, however, most of these side effects are temporary. Whole body hyperthermia may cause more serious side effects, such as cardiological and vascular disorders, but these are rare events. However, in comparison with the results achieved by the combination of chemotherapy and hyperthermia (significantly increase the patients' lifetime), it is worth using this method of treatment in oncology (22,43-46). Increasing the temperature is usually accompanied by a change 


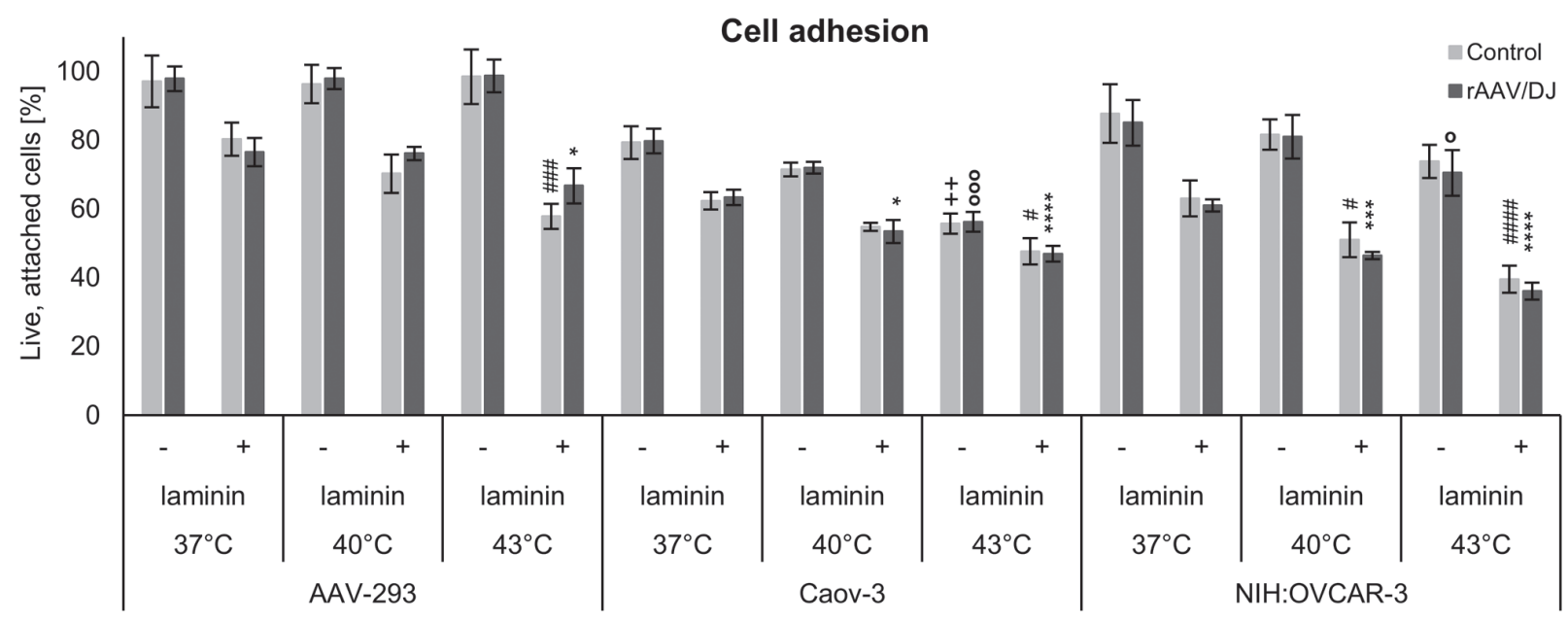

Figure 7. Adhesion of ovarian cancer cell lines (Caov-3 and NIH:OVCAR-3) and AAV-293 under hyperthermic conditions. Plates were coated with laminin. Statistically significant differences were observed between cells transduced at $37^{\circ} \mathrm{C}$ and hyperthermia conditions and similarly between control cells inubated at $37^{\circ} \mathrm{C}$ and cells exposed to higer temperatures. Data are presented as the mean \pm standard deviation. ${ }^{\circ} \mathrm{P}<0.05$ vs. $37^{\circ} \mathrm{C}$ rAAV/DJ NIH:OVCAR-3; ${ }^{\circ 00} \mathrm{P}<0.001$ vs. $37^{\circ} \mathrm{C}$ rAAV/DJ Caov- 3 ; ${ }^{*} \mathrm{P}<0.05$ vs. $37^{\circ} \mathrm{C}$ rAAV/DJ AAV- 293 or Caov- 3 ; ${ }^{* * * *} \mathrm{P}<0.001$ vs. $37^{\circ} \mathrm{C}$ rAAV/DJ NIH:OVCAR-3; ${ }^{* * * * *} \mathrm{P}<0.0001$ vs. $37^{\circ} \mathrm{C}$ rAAV/DJ Caov-3 or NIH:OVCAR-3; ${ }^{++} \mathrm{P}<0.01$ vs. $37^{\circ} \mathrm{C}$ control Caov-3; ${ }^{\#} \mathrm{P}<0.05$ vs. $37^{\circ} \mathrm{C}$ control Caov-3 or NIH:OVCAR-3; ${ }^{\# \# "} \mathrm{P}<0.001$ vs. $37^{\circ} \mathrm{C}$ control AAV-293; $\# \# \#$ P $<0.0001$ vs. $37^{\circ} \mathrm{C}$ control NIH:OVCAR-3.
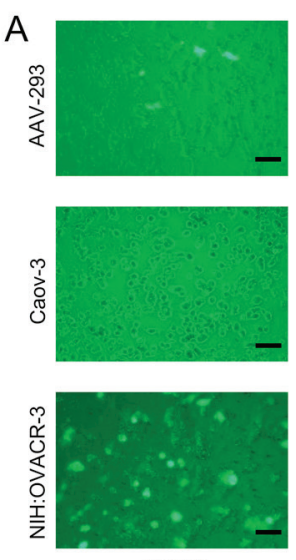

$37^{\circ} \mathrm{C}$

C

\section{Cell invasion}
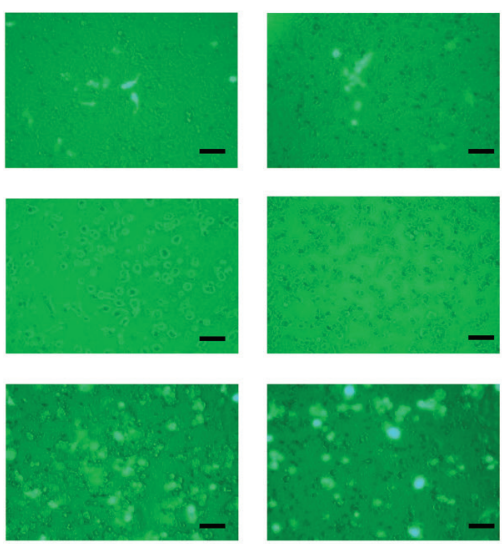

$40^{\circ} \mathrm{C}$

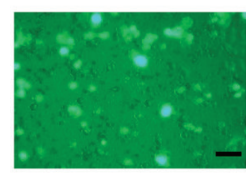

$43^{\circ} \mathrm{C}$
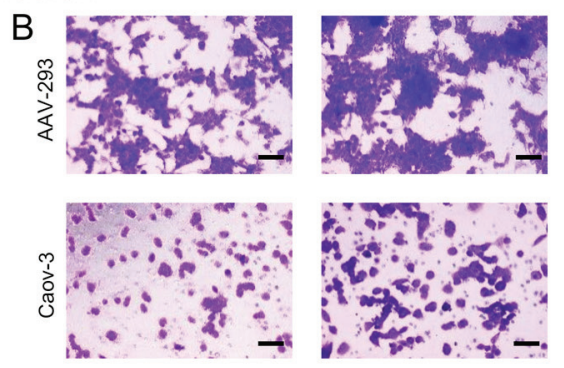

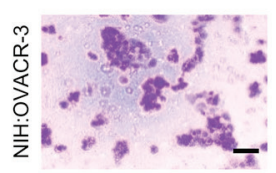

$37^{\circ} \mathrm{C}$

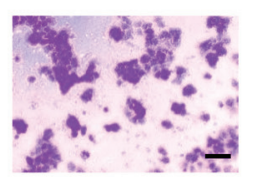

$40^{\circ} \mathrm{C}$
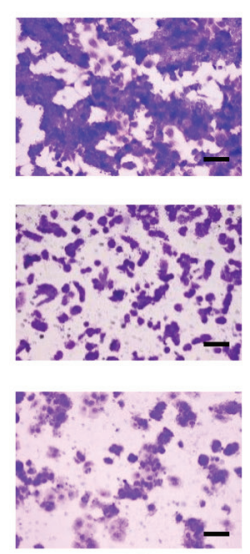

$43^{\circ} \mathrm{C}$

\begin{tabular}{|c|c|c|c|c|c|c|c|c|c|c|c|c|c|c|c|c|c|c|}
\hline & \multicolumn{6}{|c|}{ AAV-293 } & \multicolumn{6}{|c|}{ Caov-3 } & \multicolumn{6}{|c|}{ NIH:OVCAR-3 } \\
\hline & \multicolumn{2}{|c|}{$37^{\circ} \mathrm{C}$} & \multicolumn{2}{|c|}{$40^{\circ} \mathrm{C}$} & \multicolumn{2}{|c|}{$43^{\circ} \mathrm{C}$} & \multicolumn{2}{|c|}{$37^{\circ} \mathrm{C}$} & \multicolumn{2}{|c|}{$40^{\circ} \mathrm{C}$} & \multicolumn{2}{|c|}{$43^{\circ} \mathrm{C}$} & \multicolumn{2}{|c|}{$37^{\circ} \mathrm{C}$} & \multicolumn{2}{|c|}{$40^{\circ} \mathrm{C}$} & \multicolumn{2}{|c|}{$43^{\circ} \mathrm{C}$} \\
\hline & Control & rAAV/DJ & Control & rAAV/DJ & Control & rAAV/DJ & Control & rAAV/DJ & Control & rAAV/DJ & Control & rAAV/DJ & Control & rAAV/DJ & Control & rAAV/DJ & Control & rAAV/DJ \\
\hline $24 \mathrm{~h}$ & $42 \pm 4$ & $41 \pm 7$ & $45 \pm 10$ & $42 \pm 6$ & $71 \pm 6$ & $73 \pm 5$ & $73 \pm 6$ & $61 \pm 4$ & $83 \pm 3$ & $83 \pm 5$ & $125 \pm 4$ & $126 \pm 3$ & $85 \pm 6$ & $80 \pm 8$ & $110 \pm 7$ & $109 \pm 6$ & $164 \pm 17$ & $155 \pm 8$ \\
\hline $48 \mathrm{~h}$ & $47 \pm 4$ & $51 \pm 6$ & $52 \pm 8$ & $59 \pm 7$ & $75 \pm 4$ & $70 \pm 2$ & $71 \pm 3$ & $65 \pm 6$ & $81 \pm 3$ & $82 \pm 7$ & $111 \pm 8$ & $114 \pm 6$ & $81 \pm 7$ & $84 \pm 5$ & $101 \pm 2$ & $101 \pm 6$ & $155 \pm 6$ & $157 \pm 9$ \\
\hline
\end{tabular}

Figure 8. Caov-3, NIH:OVCAR-3 and AAV-293 cell invasion assays under hyperthermic conditions. (A) transduced green fluorescent protein + cells observed on the lower Matrigel chamber after $24 \mathrm{~h}$ of incubation (FITC). (B) Fixed and stained (0.5\% crystal violet) cells on the lower Matrigel chamber after $48 \mathrm{~h}$ of incubation (magnification, x10; scale bars, $100 \mu \mathrm{m}$ ). (C) Number of migrating cells. Data are presented as the mean \pm standard deviation. rAAV/DJ, recombinant adeno-associated viral hybrid serotype DJ.

in the pattern of HSP gene expression. Grimmig et al (26) emphasize the functional meaning of the increase in HSP expression in the course of chemotherapy in hyperthermia. Modern treatment of ovarian cancer is also based on the participation of gene therapy (31).

The study attempts to determine the effect of temperature on the transduction efficiency the ovarian cancer cells of various clinical origin by substantial gene therapy vectors-rAAV. Research done in the present study is a continuation of the work carried out by our team aimed at introducing genes into cancer cells $(47,48)$. Some researchers are practicing physicians and are directly involved in treating patients through hyperthermia. As shown in Fig. 2A, we reveal that increasing temperature from 37 to $40^{\circ} \mathrm{C}$ or even to $43^{\circ} \mathrm{C}$ leads to the increase of the ovarian cancer cell transduction efficiency by the rAAV/DJ vectors. In order to check the transcriptional activity of promoters, the $\mathrm{rAAV} / \mathrm{DJ}$ mosaic vector with the CAG hybrid promoter for AAV-293 cells was used in the work, while the conventional $\mathrm{cmv}$ promoter was used for ovarian cancer lines. In the case of AAV-293 (Fig. 2), $11 \%$ GFP+ cells correspond to approx. $123000 \mathrm{gc}$, while extrapolating the transduction results for the Caov-3, $11 \%$ of 
GFP+ cells would correspond to as much as $600000 \mathrm{gc}$. The obtained results indicate higher transcriptional activity of CAG promoters, compared to cmv, which is consistent with results in other studies $(49,50)$. Although the used rAAV mosaic vector is considered to have a wide range of tropism (51), in the present study, as shown in Fig. 2A, substantial differences in the transduction of tested cell lines by rAAV/DJ are evident. For ascites-derived ovarian cells, the transduction efficiency in $37^{\circ} \mathrm{C}$ was at $23 \%$, and for solid-derived cancer cells-Caov-3 at only $2 \%$. In the context of gene therapy reasons, the differences between cell transduction efficiency may have clinical importance and define the necessary selectivity of drug delivery due to development of the personalized treatment. In fact, the transduction differs depending on the cell types. In the present study, an universal vector (rAAV/DJ) was used, which is generally characterized by good transduction efficiency, regardless of the cells' origin. It is worth noting that in the gene therapy protocols the different vectors are used. The examples of efficient vectors for cells poorly transduced by rAAV are known (e.g., lentiviral vectors, adenoviral vectors). Our research is innovative, and we decided to choose one vector, which will transduce different cell lines. Differences between $\mathrm{rAAV} / \mathrm{DJ}$ transduction efficiency are not obstacle for the develop further gene therapy and hyperthermia-based treatment, because gene therapy engineering propose various types of effective vectors.

The use of elevated temperatures significantly increased the efficiency of rAAV transduction in both lines. For NIH:OVCAR-3, a $65 \%$ increase in transduction was observed at $40^{\circ} \mathrm{C}$ and $70 \%$ at $43^{\circ} \mathrm{C}$, while for Caov-3 cells, a 50 and a $200 \%$ increase, respectively. The number of copies of the vector in the transductants corresponded to the number of GFP+ cells, but only at the temperatures of 37 and $40^{\circ} \mathrm{C}$. Unexpectedly, the Caov-3 cells exposed to $43^{\circ} \mathrm{C}$ were characterized with high number of GFP+ cells and lower level of rAAV genome copies. This may suggest that hyperthermia (at higher temperatures, like $43^{\circ} \mathrm{C}$ ) activates the intracellular mechanism of vector degradation in Caov-3. On the other hand, the other lines appear to be more resistant to potential temperature-stimulated degradation.

The stimulatory effect of the elevated temperature on the performance of rAAV transduction was also demonstrated in the work of other authors. In the publication of Zhong et al (12) showed that $4 \mathrm{~h}$ exposure of Hela cells to $42,5^{\circ} \mathrm{C}$ leads to about $6 \mathrm{x}$ increase in rAAV transduction efficiency. In this study, $3 \mathrm{~h}$ stimulation was used at 40 and $43^{\circ} \mathrm{C}$. The viability cells in response to heat shock was determined at $95-98 \%$ (results not shown in the paper). The works of Zhong et al (12) and Zhao et al (52) it was revealed that the increase in rAAV transduction efficiency at a higher temperature is associated with the expression of selected HSP genes and the existence of functional connections between HSP and FKBP52 protein. The authors of the works showed that phosphorylated FKBP52 interacts with $\mathrm{D}$-sequences in inverted terminal repeats of adeno-associated virus 2 genome, which in turn leads to inhibition of second strand synthesis of AAV DNA and further to inefficient expression of reporter transgenes, i.e. a decrease in transduction efficiency. In this study, attention was paid to the expression of a comprehensive panel of HSP (HSP expression plate) genes including 42 genes predominantly from the HSP40,
HSP60, and HSP90 families. The constitutive HSP levels in cells cultured under standard conditions $\left(37^{\circ} \mathrm{C}\right)$ as well as in cells exposed to 40 and $43^{\circ} \mathrm{C}$ for $3 \mathrm{~h}$ were examined. The study allowed us to define HSP expression signature cells transduced with different levels of efficiency. Differences in constitutive and temperature-stimulated HSP expression between the cell lines were demonstrated in Figs. 5 and 6. It can be postulated that HSP specific signatures may promote rAAV transduction. Efficiently transducing NIH:OVCAR-3 cells are characterized by highly expressed HSP40 (DNAJA2, DNAJB13, DNAJB2, DNAJB4, DNAJC7), HSP90 (HSP90AA1, HSP90B1), and HSP70 (HSPA14, HSPA1A, HSPA1L, HSPA4, HSPA4L, HSPA6). Lower levels of HSP expression, mainly DNAJB1+, HSP90AB1+, HSPA5+, HSPA8+, and HSPB1+, were observed in less-effectively transduced Caov-3 cells.

In 2016, a study published in Nature was the key to determine the concept of the cellular transmission of rAAV (6). Pillay et al (6) pointed to the significant role of AAV transmembrane protein (KIAA0319L), defined as AAVR, in the transmission of rAAV. Subsequent team work expanded the knowledge of AAV transmission with the participation of AAVR $(7,8)$. This study also analyzed the expression of crucial genes of the rAAV transmission to cells. The AAVR, HSPG1 and HSPG2 genes were selected for evaluation. Differences were found in the expression pattern between the cell lines and the effect of elevated temperature on the level of expression (Fig. 3). The obtained results correspond with the literature data indicating that there are specific patterns of rAAV transmission for various cells, which are sometimes even, as recently reported by Dudek et al (7), which are independent of the expression of AAVR. The expression of the AAV transmission protein genes was also associated with the miRNA pattern in transduced cells. Based on the information available in miRNA databases and using the proposed algorithms, functional links were found between the designated miRNAs and the AAVR, HSPG1 and HSPG2 genes $(40,41)$. Based on preliminary studies, it was established that a high rAAV transduction efficiency and high levels of AAVR, HSPG1 and HSPG2 expression (Fig. 3), occur together with a lower level of miRNAs (Fig. 4) that silence the expression of AAV receptors and genes. On the other hand, in the cells with a high level of miRNA silencing (Caov-3 cells, Fig. 4), lower transduction efficiency and a lower 3-5x expression level of the tested receptors was observed. Moreover, considering our other studies on miRNA profiling in tumors, it seems that the miRNA signatures can be a valuable complement to the information panel, which should be analyzed before attempting gene therapy. In studies that are the subject of another work (based on TLDA cards that allow the evaluation of the expression of more than 700 miRNA) we have demonstrated that, for example, in breast cancer cells there is a specific miRNA signature that is helpful in choosing a vector for gene therapy trials. The clinical benefits of miRNA profiling can also be found in the work of other authors $(53,54)$.

To better understand the changes occurring in the studied cells transduced at hyperthermia, experiments for adhesion and invasion were performed. As shown in the Fig. 7, laminin reduces cell adhesion. The results demonstrated that hyperthermia induced the decrease of the number of adhered 
cells. Luchetti et al (55) showed that in cells of neuroblastoma exposed to hyperthermia, a floating population of cells increased, which had down-regulation expression of CD11a integrin molecule. Perhaps the analogous mechanism occurred for ovarian cancer and AAV-293 cells. Probably, the incubation at the increased temperature can cause change of integrins expression in cells, which in turn promoted their detachment. Furthermore, hyperthermia increased the invasiveness of all tested cells (Fig. 8), which may suggest the relation to HSPs essential for cell adhesion and invasion. For example, HSP27 is involved in the regulation of the cytoskeleton, which may affect the migration of tumor cells (56). Voll et al (57) showed that HSP27 increased in prostate cancer cell motility and invasion. Another instance can be over-expression of HSP70 enhances tumor growth, cancer cell migration and metastasis. It is postulated that the expression of HSP correlates with poor prognosis of treatment (58). In our study the expression of HSP27 in cells exposed to hyperthermia was increased in NIH:OVCAR-3, interestingly this line after incubation at $43^{\circ} \mathrm{C}$ was also characterized by the smallest percentage of cells adhered to laminin. Furthermore, NIH:OVCAR-3 showed the greatest invasion potency and had increased expression of HSP70, both constitutively and after exposed to hyperthermia. On the other hand, in study Xie et al (59) and Jin et al (60) indicated that hyperthermia could inhibit cancer cells invasion in vitro. However, the methodology details in the mentioned publications were different. It is worth underlining that the time of measurement can be an important factor, it seems that the ability to invasion/migration of cells measured directly after the exposure of cells to the high temperatures is decreased. But after a longer interval of time from hyperthermia (as documented in our study) cell migration and invasion may achieve higher results than these from original state. The time required to expression of HSP seems to be a crucial factor in cancer invasiveness.

The study showed that at elevated temperature ovarian cancer cells were more efficiently transduced with rAAV. It was also indicated that temperature-dependent transduction is in relation to the expression of the $\mathrm{rAAV}$ receptor genes and HSP genes. Moreover, hyperthermia modified the invasiveness of the studied cells. The obtained information can be helpful in the design and implementation of effective protocols for ovarian cancer gene therapy. Ovarian cancer is currently the primary cause of death among women suffering from gynecological cancer. The classic treatment protocols are not very effective. Among patients, there is a low 5-year survival rate and a high percentage of chemo-resistant cancer recurrence $(31,61)$. The need to develop new therapeutic solutions is extremely pressing. Pre-clinical studies and weak effects of clinical trials of ovarian cancer force the search for new solutions in the field of gene transfer methods (31). In the context of the results obtained in this study, it seems that the hyperthermia strategy present in oncology clinics, as a method supporting oncological treatment, may also be helpful in increasing the effectiveness of gene therapy of ovarian cancer based on $\mathrm{rAAV}$ vectors.

\section{Acknowledgements}

Not applicable.

\section{Funding}

The present study was supported by the National Centre for Research and Development (grant no. Strategmed1/233264/4/ NCBR/2014; acronym, MentorEYE).

\section{Availability of data and materials}

The datasets used and/or analyzed during the current study are available from the corresponding author on reasonable request.

\section{Authors' contributions}

$\mathrm{AB}$ and $\mathrm{MM}$ conceived and designed the experiments of the present study. $\mathrm{AB}, \mathrm{MD}, \mathrm{MO}, \mathrm{Z} \mathrm{S}$ and $\mathrm{OC}$ performed the experiments. $\mathrm{AB}, \mathrm{JJ}$ and $\mathrm{MM}$ analyzed the data. $\mathrm{AB}$ and $\mathrm{MM}$ wrote the manuscript. All authors read and approved the final manuscript.

\section{Ethics approval and consent to participate}

Not applicable.

\section{Patient consent for publication}

Not applicable.

\section{Competing interests}

The authors declare that they have no competing interests.

\section{References}

1. Naso MF, Tomkowicz B, Perry WL and Strohl WR: Adeno-associated virus (AAV) as a vector for gene therapy. BioDrugs 31: 317-334, 2017.

2. Yalkinoglu AO, Heilbronn R, Bürkle A, Schlehofer JR and zur Hausen H: DNA Amplification of adeno-associated virus as a response to cellular genotoxic stress. Cancer Res 48: 3123-3129, 1988.

3. Ginn SL, Amaya AK, Alexander IE, Edelstein M and Abedi MR: Gene therapy clinical trials worldwide to 2017: An update. J Gene Med 20: e3015, 2018.

4. Berry GE and Asokan A: Cellular transduction mechanisms of adeno-associated viral vectors. Curr Opin Virol 21: 54-60, 2016.

5. Stutika C, Mietzsch M, Gogol-Döring A, Weger S, Sohn M, Chen W and Heilbronn R: Comprehensive small RNA-seq of adeno-associated virus (AAV)-infected human cells detects patterns of novel, non-coding AAV RNAs in the absence of cellular miRNA regulation. PLoS One 11: e0161454, 2016.

6. Pillay S, Meyer NL, Puschnik AS, Davulcu O, Diep J, Ishikawa Y, Jae LT, Wosen JE, Nagamine CM, Chapman MS and Carette JE: An essential receptor for adeno-associated virus infection. Nature 530: 108-112, 2016.

7. Dudek AM, Pillay S, Puschnik AS, Nagamine CM, Cheng F, Qiu J, Carette JE and Vandenberghe LH: An alternate route for adeno-associated Virus (AAV) entry independent of AAV receptor. J Virol 92: e02213-e02217, 2018.

8. Pillay S and Carette JE: Host determinants of adeno-associated viral vector entry. Curr Opin Virol 24: 124-131, 2017.

9. Gigout L, Rebollo P, Clement N, Warrington KH Jr, Muzyczka N, Linden RM and Weber T: Altering AAV tropism with mosaic viral capsids. Mol Ther 11: 856-865, 2005.

10. McCarty DM: Self-complementary AAV vectors; advances and applications. Mol Ther 16: 1648-1656, 2008.

11. Wei F, McConnell KI, Yu TK and Suh J: Conjugation of paclitaxel on adeno-associated virus (AAV) nanoparticles for co-delivery of genes and drugs. Eur J Pharm Sci 46: 167-172, 2012. 
12. Zhong L, Qing K, Si Y, Chen L, Tan M and Srivastava A: Heat-shock treatment-mediated increase in transduction by recombinant adeno-associated virus 2 vectors is independent of the cellular heat-shock protein 90. J Biol Chem 279: 12714-12723, 2004.

13. Mitchell AM and Samulski RJ: Mechanistic insights into the enhancement of adeno-associated virus transduction by proteasome inhibitors. J Virol 87: 13035-13041, 2013

14. Berry GE and Asokan A: Chemical modulation of endocytic sorting augments adeno-associated viral transduction. J Biol Chem 291: 939-947, 2016.

15. Morrison SF and Nakamura K: Central neural pathways for thermoregulation. Front Biosci (Landmark Ed) 16: 74-104, 2011.

16. Romanovsky AA: Skin temperature: Its role in thermoregulation. Act physiol (Oxf) 210: 498-507, 2014.

17. González-Alonso J: Human thermoregulation and the cardiovascular system. Exp Physiol 97: 340-346, 2012.

18. Walter EJ, Hanna-Jumma S, Carraretto M and Forni L: The pathophysiological basis and consequences of fever. Crit Care 20: 200, 2016.

19. Mazzotta E, Tavano L and Muzzalupo R: Thermo-sensitive vesicles in controlled drug delivery for chemotherapy. Pharmaceutics 10: E150, 2018

20. Zhu X, Zhang Y, Huang H, Zhang H, Hou L and Zhang Z: Functionalized graphene oxide-based thermosensitive hydroge for near-infrared chemo-photothermal therapy on tumor. J Biomater Appl 30: 1230-1241, 2016.

21. Hildebrandt B, Wust P, Ahlers O, Dieing A, Sreenivasa G, Kerner T, Felix R and Riess H: The cellular and molecular basis of hyperthermia. Crit Rev Oncol Hematol 43: 33-56, 2002.

22. Jewell A, McMahon M and Khabele D: Heated intraperitoneal chemotherapy in the management of advanced ovarian cancer. Cancers (Basel) 10: E296, 2018.

23. Hantute-Ghesquier A, Haustrate A, Prevarskaya N and Lehen'kyi V: TRPM family channels in cancer. Pharmaceuticals (Basel) 11: 58, 2018

24. Fels B, Bulk E, Pethő $Z$ and Schwab A: The role of TRP channels in the metastatic cascade. Pharmaceuticals (Basel) 11: E48, 2018

25. Arrigo AP: Mammalian HspB1 (Hsp27) is a molecular sensor linked to the physiology and environment of the cell. Cell Stress Chaperones 22: 517-529, 2017.

26. Grimmig T, Moll EM, Kloos K, Thumm R, Moench R, Callies S, Kreckel J, Vetterlein M, Pelz J, Polat B, et al: Upregulated heat shock proteins after hyperthermic chemotherapy point to induced cell survival mechanisms in affected tumor cells from peritoneal carcinomatosis. Cancer Growth Metastasis 10 $1179064417730559,2017$.

27. Prodromou C: Mechanisms of Hsp90 regulation. Biochem J 473: 2439-2452, 2016

28. Tu Y, Tian Y, Wu Y and Cui S: Clinical significance of heat shock proteins in gastric cancer following hyperthermia stress: Indications for hyperthermic intraperitoneal chemoperfusion therapy. Oncol Lett 15: 9385-9391, 2018.

29. Stope MB, Koensgen D, Burchardt M, Concin N, Zygmunt M and Mustea A: Jump in the fire-heat shock proteins and their impact on ovarian cancer therapy. Crit Rev Oncol Hematol 97: 152-156, 2016.

30. Qing K, Hansen J, Weigel-Kelley KA, Tan M, Zhou S and Srivastava A: Adeno-Associated virus type 2-mediated gene transfer: Role of cellular FKBP52 protein in transgene expression. J Virol 75: 8968-8976, 2001.

31. Áyen Á, Jiménez Martínez Y, Marchal JA and Boulaiz H: Recent progress in gene therapy for ovarian cancer. Int J Mol Sci 19: E1930, 2018

32. Hamilton TC, Young RC, McKoy WM, Grotzinger KR Green JA, Chu EW, Whang-Peng J, Rogan AM, Green WR and Ozols RF: Characterization of a human ovarian carcinoma cell line (NIH:OVCAR-3) with androgen and estrogen receptors. Cancer Res 43: 5379-5389, 1983

33. Karlan BY, Jones J, Slamon DJ and Lagasse LD: Glucocorticoids stabilize HER-2/neu messenger RNA in human epithelial ovarian carcinoma cells. Gynecol Oncol 53: 70-77, 1994.

34. Capes-Davis A, Theodosopoulos G, Atkin I, Drexler HG, Kohara A, Macleod RA, Masters JR, Nakamura Y, Reid YA, Reddel RR and Freshney RI: Check your cultures! A list of cross-contaminated or misidentified cell lines. Int J Cancer 127: $1-8,2010$.

35. Bairoch A: The cellosaurus, a cell-line knowledge resource. J Biomol Tech 29: 25-38, 2018
36. Aurnhammer C, Haase M, Muether N, Hausl M, Rauschhuber C, Huber I, Nitschko H, Busch U, Sing A, Ehrhardt A and Baiker A: Universal real-time PCR for the detection and quantification of adeno-associated virus serotype 2-derived inverted terminal repeat sequences. Hum Gene Ther Methods 23: 18-28, 2012.

37. Livak KJ and Schmittgen, TD: Analysis of relative gene expression data using real-time quantitative PCR and the 2(-Delta Delta C(T)) method. Methods 25: 402-408, 2001

38. Bustin SA (ed): A-Z of quantitative PCR. International University Line, La Jolla, CA, 2004

39. Chomczynski P and Sacchi N: Single step method of RNA isolation by acid guanidinium thyocyanate-phenolcholoroform extraction. Anal Biochem 162: 156-159, 1987.

40. Wong N and Wang X: miRDB: An online resource for microRNA target prediction and functional annotations. Nucleic Acids Research 43 (Database Issue): D146-D152, 2015.

41. Chou CH, Shrestha S, Yang CD, Chang NW, Lin YL, Liao KW, Huang WC, Sun TH, Tu SJ, Lee WH, et al: miRTarBase update 2018: A resource for experimentally validated microRNA-target interactions. Nucleic Acids Res 46 (D1): D296-D302, 2018.

42. Dunbar CE, High KA, Joung JK, Kohn DB, Ozawa K and Sadelain M: Gene therapy comes of age. Science 359: eaan4672, 2018.

43. Turaga K, Levine E, Barone R, Sticca R, Petrelli N, Lambert L, Nash G, Morse M, Adbel-Misih R, Alexander HR, et al: Consensus guidelines from The American Society of Peritoneal Surface Malignancies on standardizing the delivery of hyperthermic intraperitoneal chemotherapy (HIPEC) in colorectal cancer patients in the United States. Ann Surg Oncol 21: 1501-1505, 2014

44. Rutkowski P, Śpiewankiewicz B, Herman K, Jastrzębski T, Kładny J, Kojs Z, Krzakowski M, Polkowski W, Wyrwicz L, Wysocki $\mathrm{P}$, et al: Polish clinical practice guideline on hyperthermic intraperitoneal chemotherapy (HIPEC) with cytoreductive surgery in peritoneal melignancy treatment. Curr Gynecol Oncol 12: 86-97, 2014.

45. van der Zee J: Heating the patient: A promising approach? Ann Oncol 13: 1173-1184, 2002.

46. Wust P, Hildebrandt B, Sreenivasa G, Rau B, Gellermann J, Riess H, Felix R and Schlag PM: Hyperthermia in combined treatment of cancer. Lancet Oncol 3: 487-497, 2002.

47. Orzechowska M, Fabijańska M, Ochocki J and Małecki M: Anticancer activity of a trans-platinum(II) complex of 3-aminoflavone to ovarian cancer cells. Ginekol Pol 88: 68-74, 2017.

48. Grecka E, Statkiewicz M, Gorska A, Biernacka M, Grygorowicz MA, Masnyk M, Chmielewski M, Gawarecka K, Chojnacki T, Swiezewska E and Malecki M: Prenyl ammonium salts-new carriers for gene delivery: A B16-F10 mouse melanoma model. PLoS One 11: e0153633, 2016.

49. Kosuga M, Enosawa S, Li XK, Suzuki S, Matsuo N, Yamada M, Roy-Chowdhury J, Koiwai O and Okuyama T: Strong, long-term transgene expression in rat liver using chicken beta-actin promoter associated with cytomegalovirus immediate-early enhancer (CAG promoter). Cell Transplant 9: 675-680, 2000

50. Damdindorj L, Karnan S, Ota A, Takahashi M, Konishi Y, Hossain E, Hosokawa $\mathrm{Y}$ and Konishi H: Assessment of the long-term transcriptional activity of a 550-bp-long human $\beta$-actin promoter region. Plasmid 68: 195-200, 2012.

51. Lerch TF, O'Donnell JK, Meyer NL, Xie Q, Taylor KA, Stagg SM and Chapman MS: Structure of AAV-DJ, a retargeted gene therapy vector: Cryo-electron microscopy at $4.5 \AA$ resolution. Structure 20: 1310-1320, 2012

52. Zhao W, Zhong L, Wu J, Chen L, Qing K, Weigel-Kelley KA, Larsen SH, Shou W, Warrington KH Jr and Srivastava A: Role of cellular FKBP52 protein in intracellular trafficking of recombinant adeno-associated virus 2 vectors. Virology 353: 283-293, 2006

53. Ganju A, Khan S, Hafeez BB, Behrman SW, Yallapu MM, Chauhan SC and Jaggi M: miRNA nanotherapeutics for cancer. Drug Discov Today 22: 424-432, 2016.

54. Hayes J, Peruzzi PP and Lawler S: MicroRNAs in cancer: Biomarkers, functions and therapy. Trends Mol Med 20: 460-469, 2014.

55. Luchetti F, Mannello F, Canonico B, Battistelli M, Burattini S, Falcieri E and Papa S: Integrin and cytoskeleton behaviour in human neuroblastoma cells during hyperthermia-related apoptosis. Apoptosis 9: 635-648, 2004. 
56. Zhang B, Xie F, Aziz AUR, Shao S, Li W, Deng S, Liao X and Liu B: Heat shock protein 27 phosphorylation regulates tumor cell migration under shear stress. Biomolecules 9: E50, 2019.

57. Voll EA, Ogden IM, Pavese JM, Huang X, Xu L, Jovanovic BD and Bergan RC: Heat shock protein 27 regulates human prostate cancer cell motility and metastatic progression. Oncotarget 5: 2648-2663, 2014.

58. Calderwood SK, Khaleque MA, Sawyer DB and Ciocca DR: Heat shock proteins in cancer: Chaperones of tumorigenesis. Treands Biochem Sci 31: 164-172, 2006.

59. Xie X, Shao X, Gao F, Jin H, Zhou J, Du L, Zhang Y, Ouyang W, Wang X, Zhao L, et al: Effect of hyperthermia on invasion ability and TGF- $\beta 1$ expression of breast carcinoma MCF-7 cells. Oncol Rep 25: 1573-1579, 2011.
60. Jin H, Xie X, Hu B, Gao F, Zhou J, Zhang Y, Du L, Wang X, Zhao L, Zhang X, et al: Hyperthermia inhibits the proliferation and invasive ability of mouse malignant melanoma through TGF- $\beta(1)$. Oncol Rep 29: 725-734, 2013.

61. Narod SA: Personalised medicine and population health: Breast and ovarian cancer. Hum Genet 137: 769-778, 2018.

(i) $\odot$ This work is licensed under a Creative Commons Attribution-NonCommercial-NoDerivatives 4.0 International (CC BY-NC-ND 4.0) License. 